\title{
Review Article \\ Plants Used as Anticancer Agents in the Ethiopian Traditional Medical Practices: A Systematic Review
}

\author{
Nigatu Tuasha $\mathbb{D}^{1},{ }^{1,2}$ Beyene Petros, ${ }^{2}$ and Zemede Asfaw ${ }^{3}$ \\ ${ }^{1}$ College of Natural and Computational Sciences, Mizan-Tepi University, P.O. Box 121, Tepi, Ethiopia \\ ${ }^{2}$ Addis Ababa University, Department of Microbial, Cellular and Molecular Biology, P.O. Box 1176, Addis Ababa, Ethiopia \\ ${ }^{3}$ Addis Ababa University, Department of Plant Biology and Biodiversity Management, P.O. Box 3434, Addis Ababa, Ethiopia \\ Correspondence should be addressed to Nigatu Tuasha; ntuasha@gmail.com
}

Received 13 March 2018; Revised 12 July 2018; Accepted 18 September 2018; Published 3 October 2018

Academic Editor: Chong-Zhi Wang

Copyright (C) 2018 Nigatu Tuasha et al. This is an open access article distributed under the Creative Commons Attribution License, which permits unrestricted use, distribution, and reproduction in any medium, provided the original work is properly cited.

\begin{abstract}
Background. This systematic review aimed at examining the use patterns of Ethiopian anticancer traditional medicinal plants (MPs) in view of recommending further validation studies. Methods. The information was retrieved from PubMed according to the PRISMA guideline. The electronic library of Addis Ababa University and relevant church-based religious books were also inspected for additional data. Results. From 34 studies meeting specific inclusion/exclusion criteria, 119 anticancer MP species distributed in 98 genera and 57 families were recorded. Fabaceae (10.92\%) and Euphorbiaceae (10.08 \%) were the most widely used families. Plumbago zeylanica (Plumbaginaceae) was the most frequently used anticancer MP species. Shrubs (42.02 \%) and herbs (35.29\%) were dominant growth forms. About $89.08 \%$ of the MPs were collected from wild habitats. Leaves (33.73\%) and roots $(27.11 \%)$ were the most frequently harvested parts. The most favored routes were dermal (33.33\%) and oral (29.25\%). About $87.07 \%$ preparations were made from fresh plant materials. Breast cancer and skin cancer were treated with $14 \%$ and $10.76 \%$ of anticancer MPs, respectively. Conclusion. The review showed that anticancer MPs are widely used across the regions of Ethiopia. Most of the MPs are not scientifically experimented and yet are at a higher vulnerability to loss mainly by human activities. Calling for conservation measures, we recommend experimental validation of the frequently used anticancer MPs. This augments global anticancer drug researches.
\end{abstract}

\section{Background}

1.1. Cancer. Cancer is the name given to a group of diseases comprising a combination of genetic, metabolic, and signaling pathway aberrations [1]. It is usually a fatal disease, which constitutes an enormous burden on society in both economically developed and underdeveloped nations alike [2]. It is the second leading cause of death globally next to cardiovascular diseases; and available estimates by GLOBOCAN (an International Agency for Research on Cancer-IARC) show that about 14.1 million new cancer cases and 8.8 million deaths occurred in 2012 worldwide. Furthermore, by 2012 32.6 million people were living with cancer, within 5 years of diagnosis [3,4]. Overall, $57 \%$ of new cancer cases, $65 \%$ of the cancer deaths, and $48 \%$ of the 5-year prevalent cancer cases occurred in the less developed regions [3]. According to WHO estimates in 2015, about 200 known types of cancer exist and the most common causes of cancer deaths include cancer of the lung (1.69 million), liver $(788,000)$, colorectal $(774,000)$, stomach $(754,000)$, and breast $(571,000)[4]$. The prevalence of cancer is increasing because of the growth and aging of the population, as well as an increasing prevalence of established risk factors such as smoking, overweight, physical inactivity, and changing reproductive patterns associated with urbanization and economic development $[3,5]$.

In Africa, cancer is alarmingly becoming a critical public health problem, with cancer forms attributed to infectious agents (e.g., cervical cancer, liver cancer, Kaposi sarcoma, and urinary bladder cancer) being the dominant types [6]. According to the IARC, about 715,000 new cancer cases and 542,000 cancer deaths occurred in 2008 in Africa [6, 7]. The numbers are projected to double by 2030 due to the aging and fast growth of the population. The potential 
of being even higher has been imagined because of the adoption of behaviors and lifestyles associated with economic development [6-9]. Thus, prostate cancer in men and breast cancer in women have now become the most commonly diagnosed cancers in some parts of Africa $[3,10]$.

Reports on the prevalence of cancer in Ethiopia are scanty and difficult to verify because oncology services are inadequate and national registry centers do not exist; there are no control and prevention programmes against the disease; diagnosis and treatment services are very limited [1113]. However, the limited reports show that Kaposi sarcoma, liver, prostate, cervical, and breast cancer are the most common cancers [14] in Ethiopia. According to the cancer country profiles of WHO, most prevalent forms among males are colorectal, Kaposi sarcoma, leukemia, lymphomas (non-Hodgkin), and prostate cancers in the order of listing, whereas cancer of the breast, cervix-uteri, ovary, colorectal, and leukemia, in the order given, are topping the list among females [15]. A study at the radiotherapy center of Tikur Anbessa specialized hospital (currently the only one in the country) showed that breast cancer had a high prevalence $(27.8 \%)$ [16]. On the scale of mortality leukemia (12.7 \%) in males and breast cancer (24.4\%) in females were reported to be the highest in 2014 [15].

1.2. Traditional Medicines and Cancer. Herbal medicine (phytomedicine, phytotherapy, or botanical medicine) is the oldest system of complementary and alternative medicine (CAM) in the world with a history of more than 2,000 years [17]. It is made exclusively from plants and is used by all societies and are common to numerous cultures [18]. There are, however, variations in the preparation and treatment procedures throughout the world [19]. Certain herbal medicines defend the body from malignancy by augmenting detoxification or cleaning the body. Some biological response modifiers derived from herbs are known to hinder the growth of cancer by modifying the activities of hormones and enzymes, while others diminish lethal side effects and complications of chemotherapy and radiotherapy [20].

The use of CAM is common among cancer patients in general and breast cancer patients, in particular [21]. They are perceived by the general public to be safe, cause less complications, and are less likely to cause dependency [19]. Most cancer patients combine herbal remedies with conventional therapy in the hope of boosting the effect of conventional medicine [22]. Nevertheless, cancer patients who use CAM report outcomes including improvement of clinical symptom, quality of life, reduction of chemo/radiotherapy induced side effects, and reduced tumor size [23-25]. Supporting conventional cancer treatment, preventing recurrence and eventual prolonging of survival were also reported [26]. In addition to these claims, anticancer agents derived from plants were shown to inhibit angiogenesis, suppress cell proliferation, inhibit or reverse tumor development, and show general antioncogenic effects [27]. A number of phytoconstituents resulting from the herbs were also reported to assist the body's immune system to combat cancer more efficiently [20].
1.3. Ethiopian Flora and Medicinal Plants. Historical accounts substantiate age-long usage of traditional medicines (TMs) in Ethiopia. For instance, collections of medicoreligious manuscripts of the Axumite kingdom, medical textbooks that have been written in Ge'ez and Arabic languages between mid- $17^{\text {th }}$ and beginning of the $18^{\text {th }}$ century are few among long-standing sources $[28,29]$. It is widely reported that over seventy percent of the Ethiopian people depend on TM for their healthcare, where more than $95 \%$ of traditional medicines are sourced from plants [30,31]. Ethiopia's location in a tropical area, its huge landmass, and incredible variation in altitude ranging from about 120 meters below sea level to 4,543 meters above sea level have strongly influenced the range of its ecosystem and have contributed to the high diversity and rate of endemism in the flora [32-34]. Thus, the flora of Ethiopia has about 6,027 species of vascular plants with $10 \%$ endemism [35-38]. According to recent reports, over 1000 species are used as traditional medicinal plants (MPs) of which about 33 species are endemic to Ethiopia $[39,40]$.

\section{The Rationale for the Systematic Review on the Anticancer MPs of Ethiopia}

It is evident that the incidence of cancer is on the rise globally. The disparity in cancer survival between high and low economic settings mainly lies on two factors: the stage of its diagnosis and availability and access to treatments [6, 81, 82]. Although surgery is the existing standard curative therapy for most cancer forms, its therapeutic efficacy is compromised as most tumors are often diagnosed at an advanced stage, particularly in the underdeveloped part of the world $[83,84]$. Therefore, treatments such as radiotherapy and chemotherapy are next ladder therapies although they achieve only very modest results [85]. The everincreasing occurrence of cancer and the severe side effects and limited efficacy of current cancer chemotherapy based on synthetic drugs shift the attention toward drugs of plant origin [86, 87].

In Ethiopia, environmental degradation, deforestation, intermittent drought, high rate of cultural and habitat loss, and various anthropogenic activities are threatening the MPs. However, recent ethnobotanical studies from different parts of the country have shown that TM is widely practiced in the country. It is also claimed that cancer patients prefer TMs to conventional therapeutic approaches mainly due to its cultural acceptance and ease of access [37, 39, 51, 52, 56, 59, 72, 73, 76, 77, 88-99]. The Ethiopian flora largely remained untouched with tremendous potential that could offer a lot in the fight against cancer. Therefore, it is believed that the systematic review of ethnobotanical studies reported from Ethiopia would help identify potential anticancer MPs. This will serve as a basis for initiating rigorous scientific investigations for the chemopreventive and anticancer attributes of the MP species most frequently used across the regions of Ethiopia. Such investigation would contribute to the global anticancer drug discovery effort. 


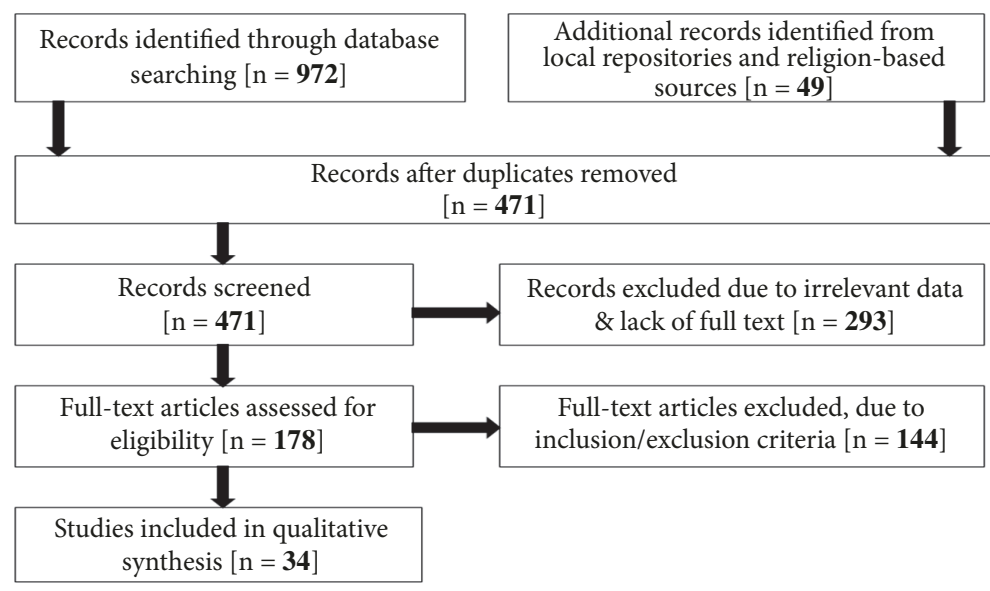

FIGURE 1: Flow of information retrieving strategy during identification, screening, and scrutinizing eligibility of the documents for the systematic review according to PRISMA suggestions.

\section{Methods}

3.1. Literature Search Strategy. Ethnobotanical studies from Ethiopia were systematically reviewed. Information included in this review spans from mid-1970s to 2017, which was the period when valid documentation on the Ethiopian TMs was undertaken. Knowledge of CAM for the treatment of various forms of cancer/malignancies in Ethiopia was retrieved from PubMed database (https://www.ncbi.nlm.nih.gov/pubmedaccessed on 25.09.2017) following "Preferred Reporting Items for Systematic Reviews and Meta-Analyses (PRISMA)" guidelines [100]. Electronic repository of the Addis Ababa University (AAU) (http://etd.aau.edu.et) and sources that make references to the TM knowledge of church-based religious teachers ('DEBTERAS') were examined as additional sources (Figure 1). In the search process, keywords including, "ethnobiology", "ethnobotany", "ethnobotanical" "ethnomedicine", "ethnomedicinal”, "medicinal plants", "traditional healer", "traditional medicine practitioner", "traditional medicine", "traditional herbal medicine "herbal medicine", "food supplements" and "medico-cultural", all with the term "Ethiopia" were used. After completing identification, screening and checking the eligibility of the literature for the systematic review, only those reporting forms of malignancies/cancer, neoplasms, 'NEKERSA', tumor and swelling due to 'NEKERSA' were analyzed. Throughout the review paper the term "cancer" or 'NEKERSA' or "malignancy" is used to define a condition where cells of neoplastic features divide without control and can invade nearby tissues.

3.2. Inclusion and Exclusion Criteria. Information obtained from the database and other sources were scrutinized based on the following conditions. Published articles and unpublished thesis/dissertation on ethnomedicinal/ethnobotanical surveys reporting MPs used in Ethiopia to treat various forms of malignancies/cancer were included.

Researches reporting (i) CAM used for the treatment of single etiology; (ii) ethnoveterinary research reports; (iii) review articles; (iv) published in languages other than
English; (v) lacking clear objectives and methodologies; (vi) abstract only or without full text access; (vii) experimental studies; (viii) articles lacking scientific plant names; (ix) research reports without voucher numbers of the specimens; and $(\mathrm{x})$ ethnobotanical information with no reports of MP use for the treatment of malignancies/cancer and/or any neoplasm were excluded.

3.3. Data Extraction and Review Process. After the retrieval from the electronic databases, the research articles were imported to the ENDNOTE software version X7 (Thomson Reuters, USA) and the duplicates were removed. After the removal of the duplicates, all the imported articles and the additional files were checked against the inclusion/exclusion criteria. Following the confirmation of the eligibility for the systematic review, each document was carefully examined at a time. We extracted the following data from each eligible document: (i) taxonomic diversity (the scientific name of the species and family name), (ii) vernacular/local name of the plant, (iii) habitat of the plant, (iv) the growth form (habit of the MP), (v) parts of the MPs used for the remedy preparation and routes of administration, (vi) the forms of malignancies treated, and (vii) reports on the adverse effect(s); contraindications and antidotes were carefully extracted and analyzed. The citation frequency and mapping of their geospatial distribution were done. Data on the distribution of MPs in the Ethiopian flora region and the altitudinal range the plants grow was generated. Data extraction was carried out twice independently and the data sheet was further checked for methodological conformity and correction of any discordance. Descriptive statistics was used to summarize the findings.

\section{Results}

4.1. Taxonomic Diversity and Growth form and Distribution of the Anticancer MPs of Ethiopia. One hundred nineteen (119) species of anticancer MPs distributed in 98 genera and 57 families were retrieved from thirty-four (34) reports that 
TABLE 1: The taxonomic distribution of anticancer MPs of Ethiopian flora.

\begin{tabular}{lcc}
\hline Family $(\mathbf{N = 5 7 )}$ & Genera N (\%) & Species N (\%) \\
\hline Fabaceae & $9(9.18)$ & $13(10.92)$ \\
Euphorbiaceae & $7(7.14)$ & $12(10.08)$ \\
Asteraceae & $4(4.08)$ & $6(5.04)$ \\
Lamiaceae & $5(5.10)$ & $6(5.04)$ \\
Ranunculaceae & $3(3.06)$ & $5(4.2)$ \\
Cucurbitaceae & $3(3.06)$ & $3(2.52)$ \\
Rosaceae & $3(3.06)$ & $3(2.52)$ \\
Solanaceae & $3(3.06)$ & $3(2.52)$ \\
Other 49 families & $61(62.24)$ & $68(57.14)$ \\
\hline Total & $\mathbf{9 8 ( 1 0 0 \% )}$ & $\mathbf{1 1 9 ( 1 0 0 \% )}$ \\
\hline
\end{tabular}

TABLE 2: Frequently cited anticancer MPs from different parts of Ethiopia.

\begin{tabular}{|c|c|c|c|c|}
\hline Scientific Name [Family] & $\begin{array}{l}\text { Part(s) of the MP(s) } \\
\text { used }\end{array}$ & Total reports & $\begin{array}{l}\text { Areas/regions the } \\
\mathrm{MP}(\mathrm{s}) \text { are used as } \\
\text { anticancer agent }\end{array}$ & References \\
\hline $\begin{array}{l}\text { Plumbago zeylanica } \\
\text { [Plumbaginaceae] }\end{array}$ & Lf, Rt and Sh & 5 & $\begin{array}{c}\text { Jeldesa Cluster (Dire } \\
\text { Dawa) } \\
\text { Mecha District, Zegie } \\
\text { Peninsula, Ghimbi } \\
\text { District and across the } \\
\text { regions }\end{array}$ & {$[41-45]$} \\
\hline $\begin{array}{l}\text { Brucea antidysenterica } \\
\text { [Simaroubaceae] }\end{array}$ & Lf, St and Br & 3 & $\begin{array}{c}\text { Jimma Zone, Bale Zone } \\
\text { and } \\
\text { Fiche District }\end{array}$ & {$[46-48]$} \\
\hline $\begin{array}{l}\text { Clematis hirsuta var. hirsute } \\
\text { [Ranunculaceae] }\end{array}$ & Lf, St and Br & 3 & $\begin{array}{l}\text { Wondo Genet; Dega } \\
\text { Damot and Blue Hora }\end{array}$ & [49-51] \\
\hline $\begin{array}{l}\text { Croton macrostachyus } \\
\text { [Euphorbiaceae] }\end{array}$ & Lf & 3 & $\begin{array}{l}\text { Wondo Genet, Hawassa } \\
\text { city, and Dalle District }\end{array}$ & {$[37,51,52]$} \\
\hline $\begin{array}{l}\text { Dodonaea angustirolia } \\
\text { [Sapindaceae] }\end{array}$ & Lf & 3 & $\begin{array}{c}\text { Dalle District (different } \\
\text { sites) and Debre Libanos } \\
\text { monastery }\end{array}$ & {$[45,52,53]$} \\
\hline Dovyalis abyssinica [Flacourtiaceae] & Fr, $\mathrm{Br}$ and $\mathrm{WP}$ & 3 & $\begin{array}{c}\text { Fiche District, Dalle } \\
\text { District and across the } \\
\text { regions }\end{array}$ & {$[45,54,55]$} \\
\hline $\begin{array}{l}\text { Vernonia leopoldi (bitter leaf) } \\
\text { [Asteraceae] }\end{array}$ & Lf & 3 & $\begin{array}{l}\text { Jimma area, Bale Zone, } \\
\text { and Zegie Peninsula }\end{array}$ & {$[44,47,48]$} \\
\hline Zanthoxylum chalybeum [Rutaceae] & Lf and Rt & 3 & $\begin{array}{l}\text { Hawassa city and Dalle } \\
\text { District (different sites) }\end{array}$ & {$[52,55,56]$} \\
\hline
\end{tabular}

Note: Parts Used: $\mathrm{Lf}=\mathrm{Leaf} ; \mathrm{Rt}=\mathrm{Root} ; \mathrm{Fr}=\mathrm{Fruit} ; \mathrm{Br}=\mathrm{Bark}$; $\mathrm{Sh}=\mathrm{Shoot} ; \mathrm{St}=\mathrm{Stem}$.

fulfilled the inclusion/exclusion criteria (Table 1). Twenty-five (25) families were represented by two or more anticancer MPs, whereas 32 families were represented by a single species each (Appendix). The families Fabaceae (10.92 \%) and Euphorbiaceae $(10.08 \%)$ were represented by the highest number of anticancer MP species followed by the families Asteraceae and Lamiaceae (5.04 \% each). Eight (8) anticancer MP species were found to be widely used in different regions of the country, where the species Plumbago zeylanica (family Plumbaginaceae) being the most frequently used in areas including Jeldesa Cluster (Dire Dawa city administration), Mecha and Ghimbi Districts of Oromia Regional State and Zegie Peninsula, Amhara regional state (Table 2). The life forms of the anticancer MPs are constituted shrubs (42.02 $\%)$, herbs (35.29\%), trees (18.49\%), and climber/liana (4.2 $\%)$. A total of $89.08 \%$ of the MPs are found in the wild habitats; home gardens make up $9.24 \%$ and the remaining $1.68 \%$ are found, both in the wild and home gardens. About $8.4 \%$ of anticancer MP species are endemic, $86.56 \%$ are indigenous, and $5.04 \%$ are introduced from elsewhere. 
TABLE 3: Geospatial distribution of the ethnobotanical studies that reported the use of CAM for the treatment of any form of malignancies/cancer atregional/city administration level.

\begin{tabular}{lc}
\hline Region/city administration of the Federal Democratic Republic of Ethiopia & Frequency (\%) \\
\hline Oromia Regional State & $10(37.04)$ \\
Amhara Regional State & $9(33.33)$ \\
SNNPR State & $5(18.52)$ \\
Tigray Regional State & $1(3.70)$ \\
Dire Dawa City Administration & $1(3.70)$ \\
Afar Regional State & $1(3.70)$ \\
\hline Total reports & $\mathbf{2 7 ( 1 0 0 )}$ \\
\hline
\end{tabular}

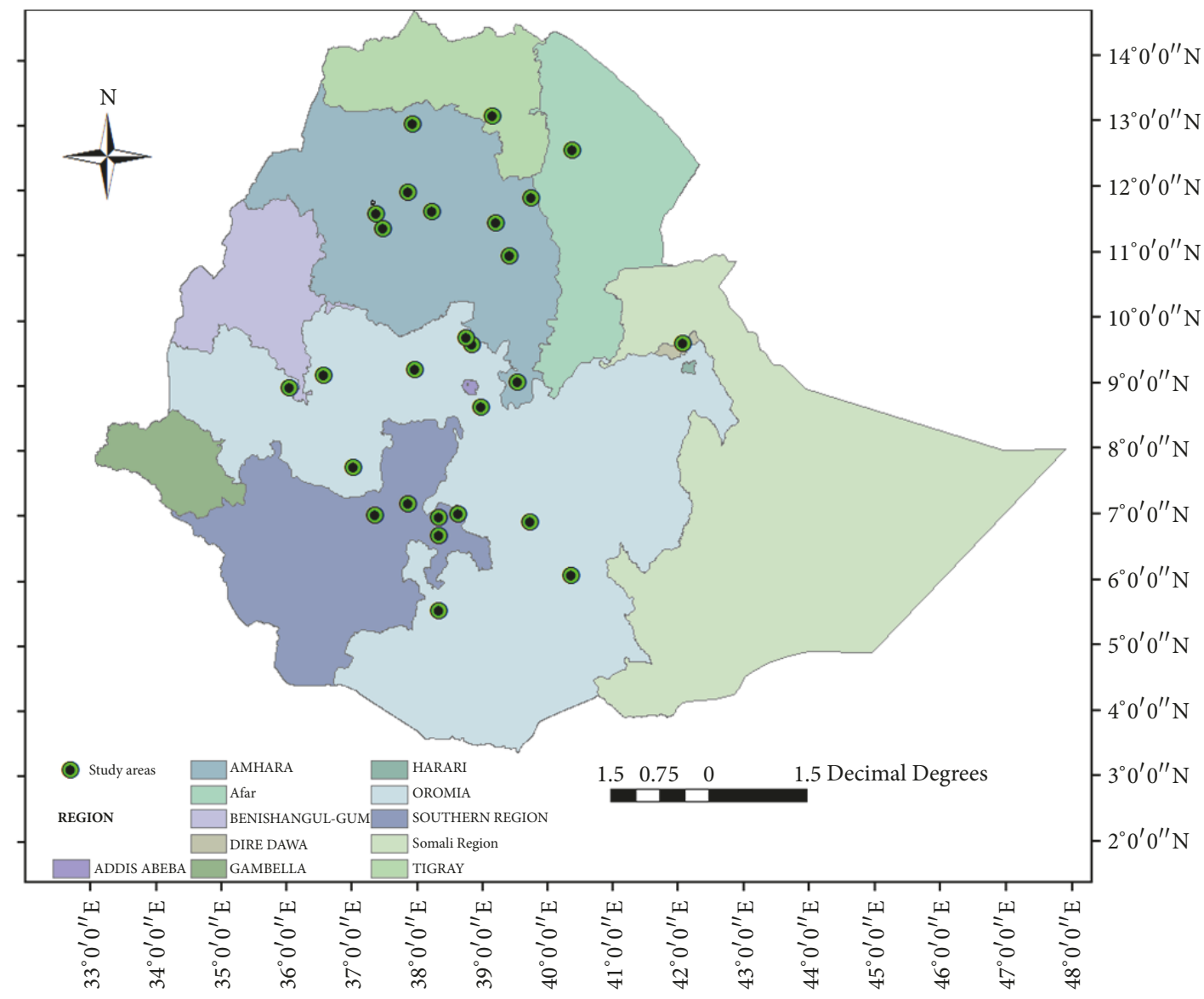

FIGURE 2: The geographical distribution of the Ethiopian anticancer traditional MPs.

Bidens macroptera (Sch Bip.) ex Chiov. Mesfin, Erythrina brucei Schweinf., Euphorbia heterochroma Pax., Galium boreoaethiopicum Puff., Lobelia rhynchopetalum (Hochst.) Hemsl, Millettia ferruginea (Hochst.) Baker, Pittosporum abyssinicum Del., Plectocephalus varians (A. Rich) Jeffrey ex Cufod., Sideroxylon oxyacanthum Baill, and Vernonia leopoldi (Sch. Bip. ex Walp.) Vatke are endemic to Ethiopia [39, 101, 102].

4.2. Geospatial Distribution of the Anticancer MPs. According to the present systematic review, the eligible studies on anticancer MPs were reported mainly from the Oromia
Regional State (37.04\%), Amhara Regional State (33.33\%), and Southern Nations, Nationalities and Peoples Regional (SNNPR) State (18.52\%) (Table 3). The frequency of reports across the regions and distribution in the Ethiopian Flora Region are shown in Figure 2 and Appendix.

4.3. Forms of Malignancies Most Frequently Treated by Traditional MPs. A variety of malignancies or cancer forms were reported to be treated with traditional MPs in Ethiopia. In the higher number of the reports $(43.33 \%)$, it was reported as "cancer/ 'NEKERSA" nonspecifically. Specific forms of 


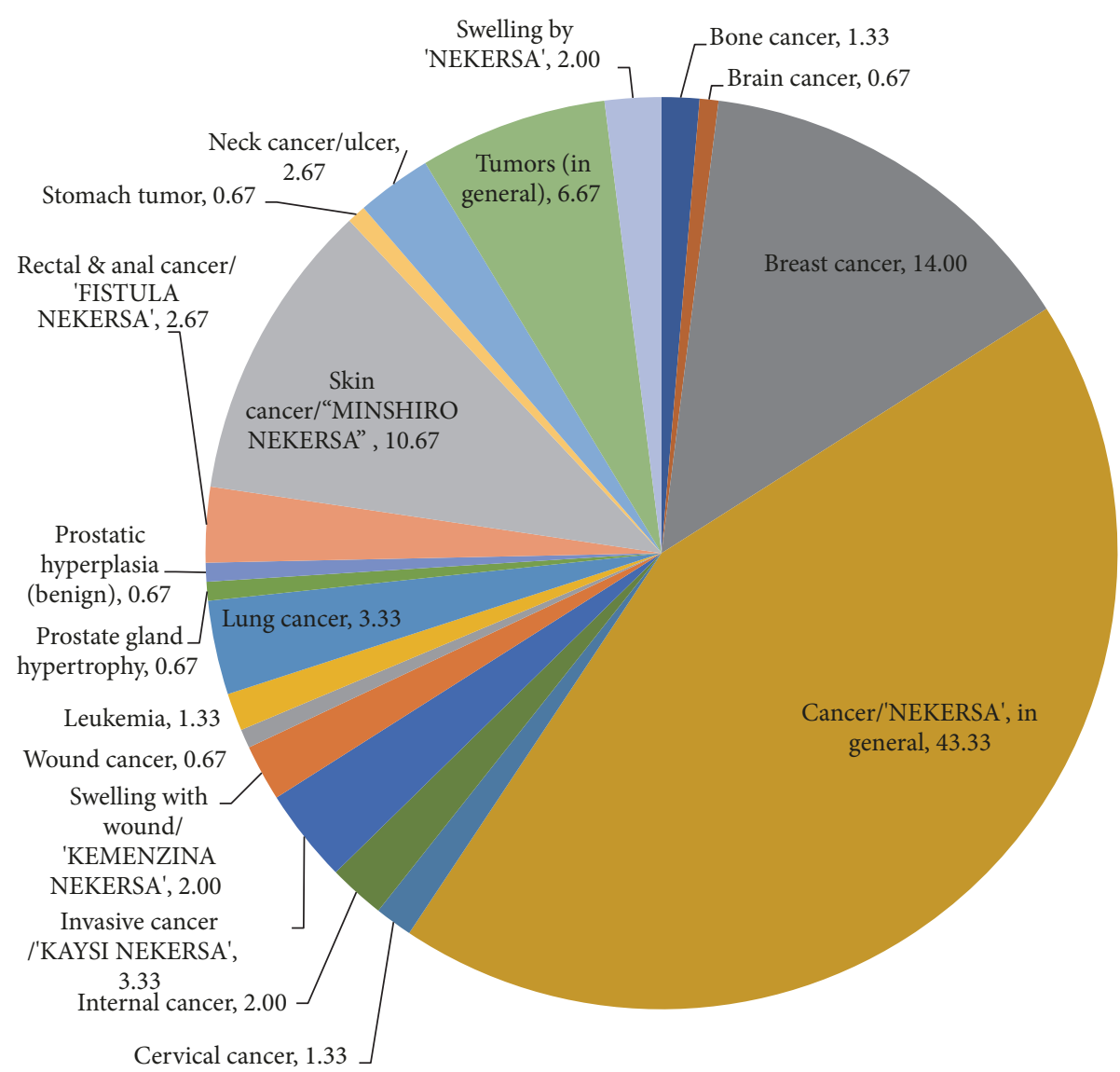

FIgURE 3: Types and frequency of cancer forms treated by traditional MPs in Ethiopia (\%).

cancer reported include breast cancer $(14.0 \%)$ and skin cancer/'Minshiro NEKERSA' (10.67\%). The remaining list includes bone cancer, brain cancer, cervical cancer, rectal cancer, anal cancer, invasive cancer/ 'KAYSI NEKERSA', swelling with wound/'KEMENZINA NEKERSA', leukemia, and lung cancer among others (Figure 3).

4.4. Parts of the MPs Used for the Remedy Preparation and Routes of Administration. Analysis of the eligible ethnobotanical findings showed that various parts of the anticancer MPs were used for the remedy preparation. The most frequently harvested parts of the anticancer MPs are leaves $(33.73 \%)$ and roots $(27.11 \%)$. Debarking constituted 10.84 $\%$ whereas the whole parts of the MPs were used in as high as $4.22 \%$ of the preparations. The stem and shoots were rarely collected (only $1.81 \%$, each) for the remedy preparation (Figure 4).

From the various formulations and application procedures reported, the most preferred administration route of the TMs was dermal application (33.33\%) followed by oral (29.25\%). About $4.08 \%$ of the applications recommend both oral and dermal routes of applications and in $26.53 \%$ of the cases, the route of administration has not been specified (Figure 5). About $12.93 \%$ of the preparations were made from dried plant materials whereas $87.07 \%$ were prepared from fresh plant materials and water is the solvent that is mostly used to prepare anticancer TMs. About $4.76 \%$ of preparations included honey as an additive to the remedy. Butter, flour of 'TEFF', spicy stew, and sulfur (locally called 'DIGNE' in Amharic) among others were found to be mixed in about $4.08 \%$ of the remedies. Common methods of dermal application included dressing the swelling with warm plant material, smearing on the wound, rubbing the affected area with the TM, tying the residue on the swelling, and giving a message with the fresh plant material preparation, as in the cases of breast and skin cancer.

4.5. Adverse Effects, Contraindications Implicated, and Antidotes. The present finding revealed that nine eligible studies discussed the existence and management approaches used by the TM practitioners in case the anticancer remedies cause any possible side effect(s). Besides, contraindications were also noted, pregnant women being the most commonly at risk. Out of 119 MP species compiled, eleven (11) species were found to have adverse side effects and/or contraindications. The most commonly implicated species was Phytolacca dodecandra, followed by Croton macrostachyus. Two studies have reported that any MP could result in mild adverse effects especially among the risk groups or in case of overdosing of the remedy. During such circumstances, drinking coffee, 


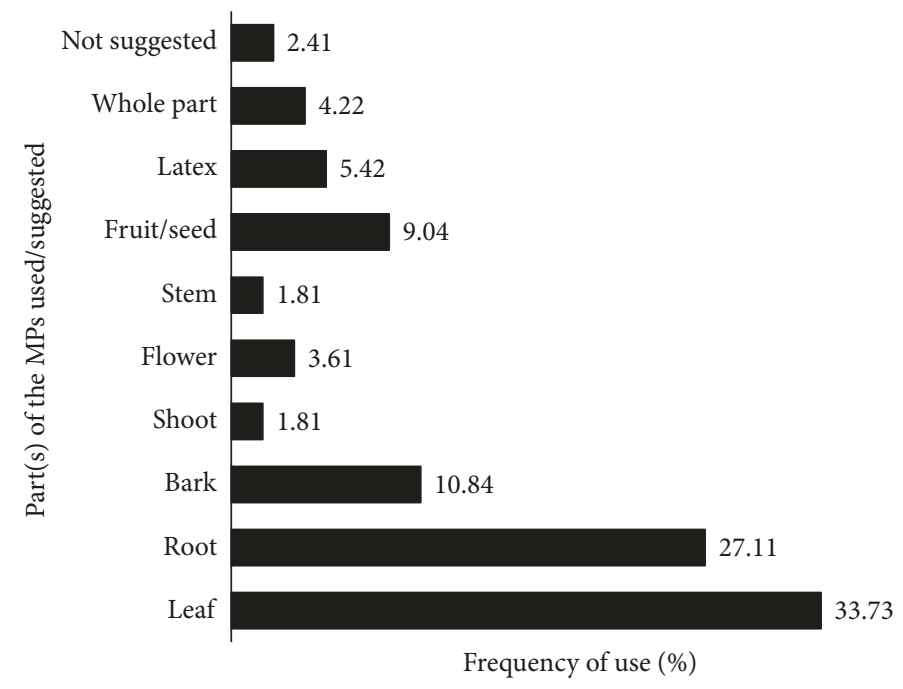

FIGURE 4: Part(s) of the anticancer MPs used/suggested for the treatment of various forms of cancer.

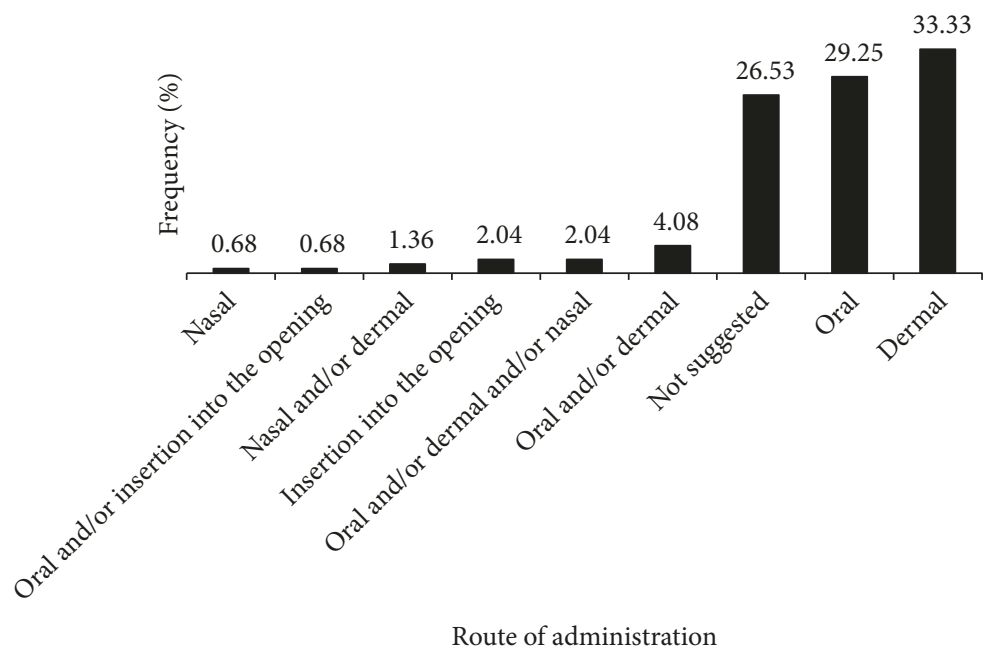

FIGURE 5: Routes of anticancer TM remedy administration.

local beer and flax, and eating local food like 'SHIRO' alleviates the symptoms $[41,69]$. The findings are summarized along with the recommended antidote(s) (Table 4).

\section{Discussion}

These days, there is a higher level of dynamics in sociocultural transformations in Ethiopia. It is evident, however, that the communities by and large retained valuable knowledge of the MPs and their uses with regard to traditional healthcare. In the present investigation, 119 anticancer MPs were documented. This implies a wider usage of CAM among cancer patients in Ethiopia. This could be related to lack of full access to healthcare facilities. In addition, CAM usage is culturally accepted among Ethiopians as an effective cure and safe and is affordable. It is also perceived more efficacious against certain types of diseases including cancer [103-105]. However, the rapid population growth has resulted in an alarmingly high demand for agricultural land which in turn seriously threatens forest cover and hence the MPs. This makes designing and implementing of an insightful conservation program mandatory $[29,30,106]$.

Consistent with various ethnobotanical studies, shrubs made up a larger proportion of the anticancer MPs (42.02 $\%)$ followed by herbs (35.29 \%) [31, 44, 97, 107-109]. This may be explained by the fact that shrubs are perennial in the arid or subarid environments and may be available for use as MPs [64]. The dominance of certain life forms of MPs in different study areas might be explained by their availability and adaptation in the particular ecological setting and the dynamics involved due to bushy vegetation being left behind when the forest recedes.

Dominant families from which anticancer MPs are prepared were found to be Fabaceae (13 MP species, $10.92 \%$ ), Euphorbiaceae (12 MP species, $10.08 \%$ ), and Lamiaceae and Asteraceae (six MP species, $5.04 \%$, each). This could be 
TABLE 4: Adverse/side effects, contraindication implicated, and possible antidote.

\begin{tabular}{|c|c|c|c|c|}
\hline Family & MP (s) involved & Contraindication (if any) & $\begin{array}{l}\text { Adverse effect(s); [possible } \\
\text { antidote recommended] (if } \\
\text { any) }\end{array}$ & Reference \\
\hline Asteraceae & Vernonia Amygdalina, & Pregnant women & A headache and diarrhea & {$[50,57]$} \\
\hline Cucurbitaceae & Zehneria scabra & - & $\begin{array}{l}\text { A headache, vomiting, and } \\
\text { diarrhea [Taking shower] }\end{array}$ & {$[50,57]$} \\
\hline \multirow[t]{3}{*}{ Euphorbiaceae } & \multirow[t]{3}{*}{ Croton macrostachyus } & Pregnant women & $\begin{array}{c}\text { A headache, vomiting, } \\
\text { diarrhea, urination; } \\
\text { [“TeFF INJERA" and porridge } \\
\text { are anecdotes] }\end{array}$ & {$[50,57]$} \\
\hline & & - & $\begin{array}{c}\text { Any; [milk whey as an } \\
\text { antidote] }\end{array}$ & {$[58]$} \\
\hline & & Pregnant women & $\begin{array}{c}\text { Nausea, vomiting and } \\
\text { diarrhea }\end{array}$ & [59] \\
\hline \multirow{2}{*}{ Fabaceae } & Calpurnia aurea & - & headache & {$[57]$} \\
\hline & Millettia ferruginea & Pregnant women & $\begin{array}{c}\text { Nausea, vomiting and } \\
\text { diarrhea }\end{array}$ & {$[59]$} \\
\hline Lobeliaceae & Lobelia rhynchopetalum & - & $\begin{array}{l}\text { Vomiting and diarrhea; } \\
\text { ["SHIRO WOT" (sauce made } \\
\text { of pulse grains) and powder } \\
\text { of Linum usitatissimum } \\
\text { infusion in water] }\end{array}$ & {$[60]$} \\
\hline Menispermaceae & Stephania abyssinica & - & $\begin{array}{c}\text { Any; [milk whey as an } \\
\text { antidote] }\end{array}$ & {$[58]$} \\
\hline \multirow{5}{*}{ Phytolaccaceae } & \multirow{5}{*}{ Phytolacca dodecandra } & Pregnant women & $\begin{array}{l}\text { Overdosage would result in } \\
\text { death }\end{array}$ & {$[53]$} \\
\hline & & $\begin{array}{l}\text { Women at a child-bearing } \\
\text { age }\end{array}$ & $\begin{array}{l}\text { Could result in sterility in } \\
\text { women }\end{array}$ & {$[46]$} \\
\hline & & - & $\begin{array}{l}\text { Vomiting and diarrhea; } \\
\text { ["SHIRO WOT" (sauce made } \\
\text { of pulse grains) and powder } \\
\text { of Linum usitatissimum } \\
\text { infusion in water] }\end{array}$ & {$[60]$} \\
\hline & & $\begin{array}{l}\text { Children and pregnant } \\
\text { women }\end{array}$ & $\begin{array}{l}\text { Vomiting and diarrhea; [milk } \\
\text { and red "TEFF" PORRIDGE] }\end{array}$ & {$[50,57]$} \\
\hline & & Pregnant women & $\begin{array}{c}\text { Nausea, vomiting and } \\
\text { diarrhea }\end{array}$ & {$[59]$} \\
\hline Polygonaceae & Rumex nervosus & Children & $\begin{array}{l}\text { Vomiting and diarrhea; [red } \\
\text { "TEFF' PORRIDGE] }\end{array}$ & {$[50,57]$} \\
\hline Ranunculaceae & $\begin{array}{l}\text { Clematis hirsuta var. } \\
\text { hirsuta }\end{array}$ & - & $\begin{array}{c}\text { A headache, Sweating, and } \\
\text { diarrhea }\end{array}$ & {$[50,57]$} \\
\hline \multirow[t]{2}{*}{ Rosaceae } & \multirow[t]{2}{*}{ Hagenia abyssinica } & \multirow[t]{2}{*}{-} & $\begin{array}{c}\text { A headache, vomiting, and } \\
\text { diarrhea }\end{array}$ & {$[50,57]$} \\
\hline & & & $\begin{array}{l}\text { ["SHIRO WOT" (sauce made } \\
\text { of pulse grains) and powder } \\
\text { of Linum usitatissimum } \\
\text { infusion in water] }\end{array}$ & {$[60]$} \\
\hline
\end{tabular}

attributed to the fact that these families are among the most widely distributed ones in the Ethiopian Flora Regions [31, 67, 110]. Since Plumbago zeylanica (Plumbaginaceae) is the anticancer MP species most widely used across the country, it may have a better healing potential over other anticancer MPs. This finding would make it a prime candidate for further in-depth experimental investigations.
The present review also revealed that roots (27.11\%), bark (10.84\%), and the whole part of the MPs (4.22\%) accounted for about $42.17 \%$ usage in TM. This will significantly affect the sustainability of the MPs unlike use of aerial parts, such as leaves [91, 106, 111]. It was revealed that most remedies are prepared from fresh plant materials $(87.07 \%)$. This would result in the extensive exploitation of the MPs and in a long 
run and will compromise the sustainability of the MPs [55, $58,111]$.

The finding that a significant proportion of the remedies were given orally $(29.25 \%)$ implies that the remedies are safe for systemic applications. However, in the present report over ten MP species used as anticancer agents across the country had contraindications and/or adverse effects calls for cautionary usage. In addition, there are experimental evidences on the toxicity of some anticancer MPs (e.g., Hagenia abyssinica and the species from genus Vernonia) reported in the present study [112-114]. This indicates the need for acute and chronic toxicity investigations on the most commonly used traditional anticancer MPs.

The majority of anticancer MPs reported in the present study were from wild habitats $(89.08 \%)$. These habitats are vulnerable to demise by anthropogenic activities $[57,115]$. As intermittent drought and wide spreading climatic changes are posing additional threats to the anticancer MPs of the country, they are limited to inaccessible areas. Therefore, as d'Avigdor and the coworkers suggested, the community must be encouraged to grow them in and around home gardens and backyard [46].

One of the greatest challenges in ethnomedicinal researches is the issue of access and benefit sharing (ABS) and that of intellectual property rights. WHO states that "agreements on the return of immediate and/or long-term benefits and compensation for the use of MP materials and associated community knowledge must be discussed and concluded" [116]. In the year 1986, there were over 6,000 TM practitioners in the country registered with the Ethiopian Ministry of Health [117]. However, there is no national guideline to address the regulatory situation [118]. The proclamation, which was issued based on the National Drug Policy in 1999 in Article 6, Sub-Article 8 states, "the Drug Administration and Control Authority shall prepare standards of safety, efficacy, and quality of TMs and shall evaluate laboratory and clinical studies in order to ensure that these standards are met". It states that the authority shall also issue licenses for the use of TMs in the official health services. However, there were no official education and training systems to strengthen the TM practitioners in addition to the lack of regulation to address the issue of property rights and benefit sharing [117].

In Ethiopia, there have been attempts to implement $\mathrm{ABS}$ system of the Convention on Biological Diversity (CBD) according to the provisions in the Nagoya Protocol and other international agreements [119-121]. The country has acceded to it and developed a code of conduct to administer the ABS regime. However, there are several unmet issues requiring resolution $[119,120]$.

\section{Conclusion}

From the present study, it can be concluded that CAM practice is an integral part of the primary healthcare system of Ethiopians, where the traditional anticancer MPs are reported from different corners of the country. The majority of anticancer MPs are found in wild habitats. This shows that most MPs are vulnerable to destructive anthropogenic activities directed against forests and other environmental factors including climate variability. Thus, due attention should be given to conserving these valuable resources in addition to raising awareness of the community on how to use these plants sustainably.

We also call for the proper enforcement of the Nagoya Protocol with all its international recommendations and in accordance with the national setups in order to protect the TM knowledge and associated rights of indigenous communities. This will further not only grant an opportunity to salvage the indigenous knowledge held by the communities, but also help the scientific endeavor in plant-based anticancer and other diseases drug discoveries.

The efficacies of most Ethiopian traditional anticancer treatment claims with the MPs are not validated scientifically. Besides, only a small proportion of the MPs were reported to have side effects and/or contraindications. To avoid such overlooked health risks, we recommend further assessment on the safety of the anticancer MPs. Scientific investigation on the MP's potential toxicity and anticancer efficacy must also be made. This would possibly provide a lead material to a more thorough anticancer drug development researches.

\section{Appendix}

See Table 5.

\section{Abbreviations \\ AAU: $\quad$ Addis Ababa University \\ ABS: $\quad$ Access and benefit sharing \\ CAM: Complementary and alternative medicine \\ IARC: International Agency for Research on Cancer \\ MP/MPs: Medicinal plant(s) \\ SNNP: Southern Nations, Nationalities and Peoples \\ TM/TMs: Traditional medicine(s) \\ WHO: World Health Organization.}

\section{Disclosure}

This work did not receive any specific grant from funding agencies in the public, commercial, or not-for-profit sectors.

\section{Conflicts of Interest}

The authors declare that they have no conflicts of interest.

\section{Authors' Contributions}

Nigatu Tuasha has incepted and designed this systematic review, searched the literature, screened the literature for eligibility against inclusion/exclusion criteria, extracted the data, carried out the analysis of the results, and prepared the draft manuscript. Beyene Petros and Zemede Asfaw independently checked for the methodological conformity, corrected the discordance, provided consistent comments during the analysis and write-up, and rigorously reviewed the 


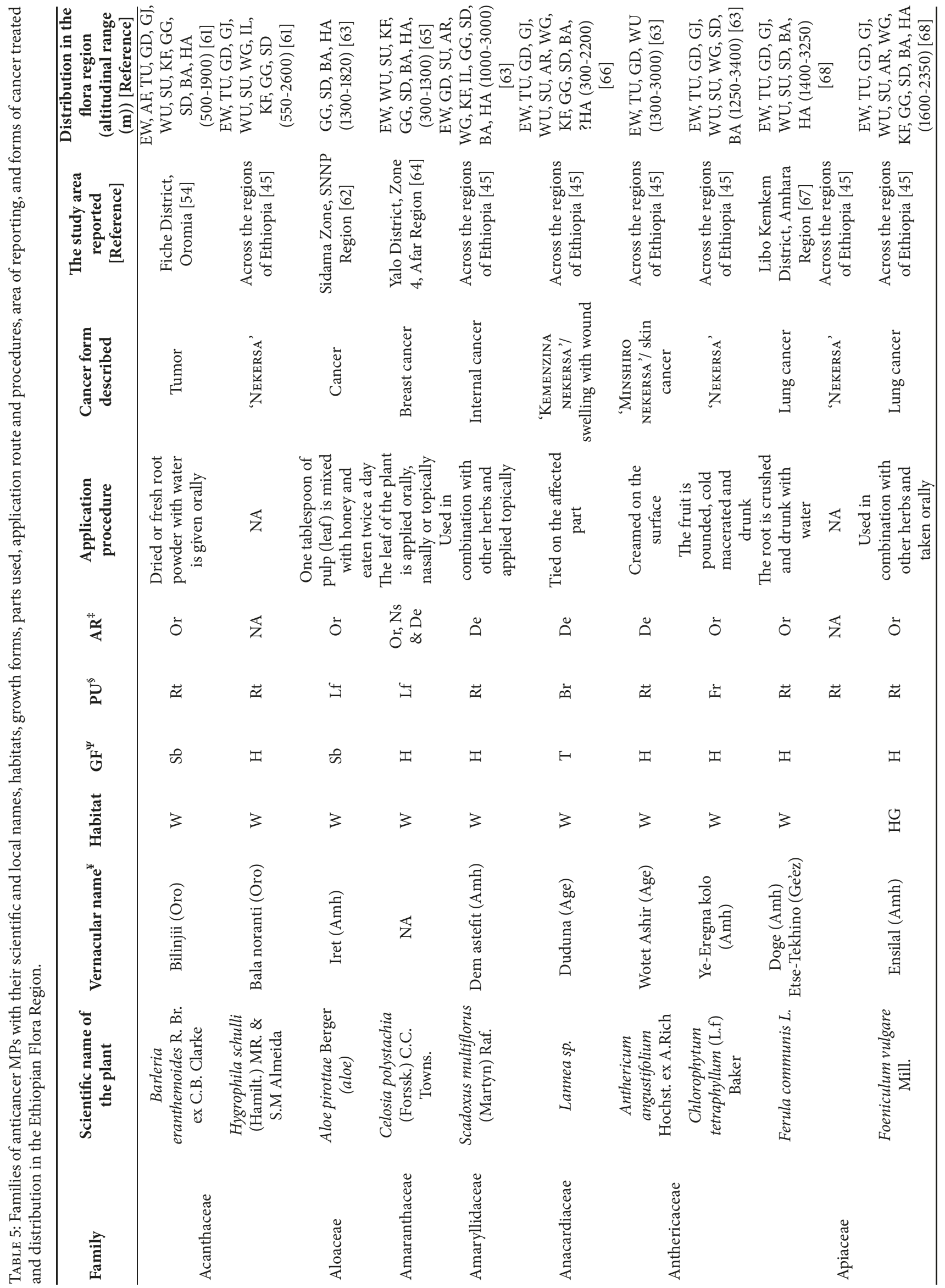




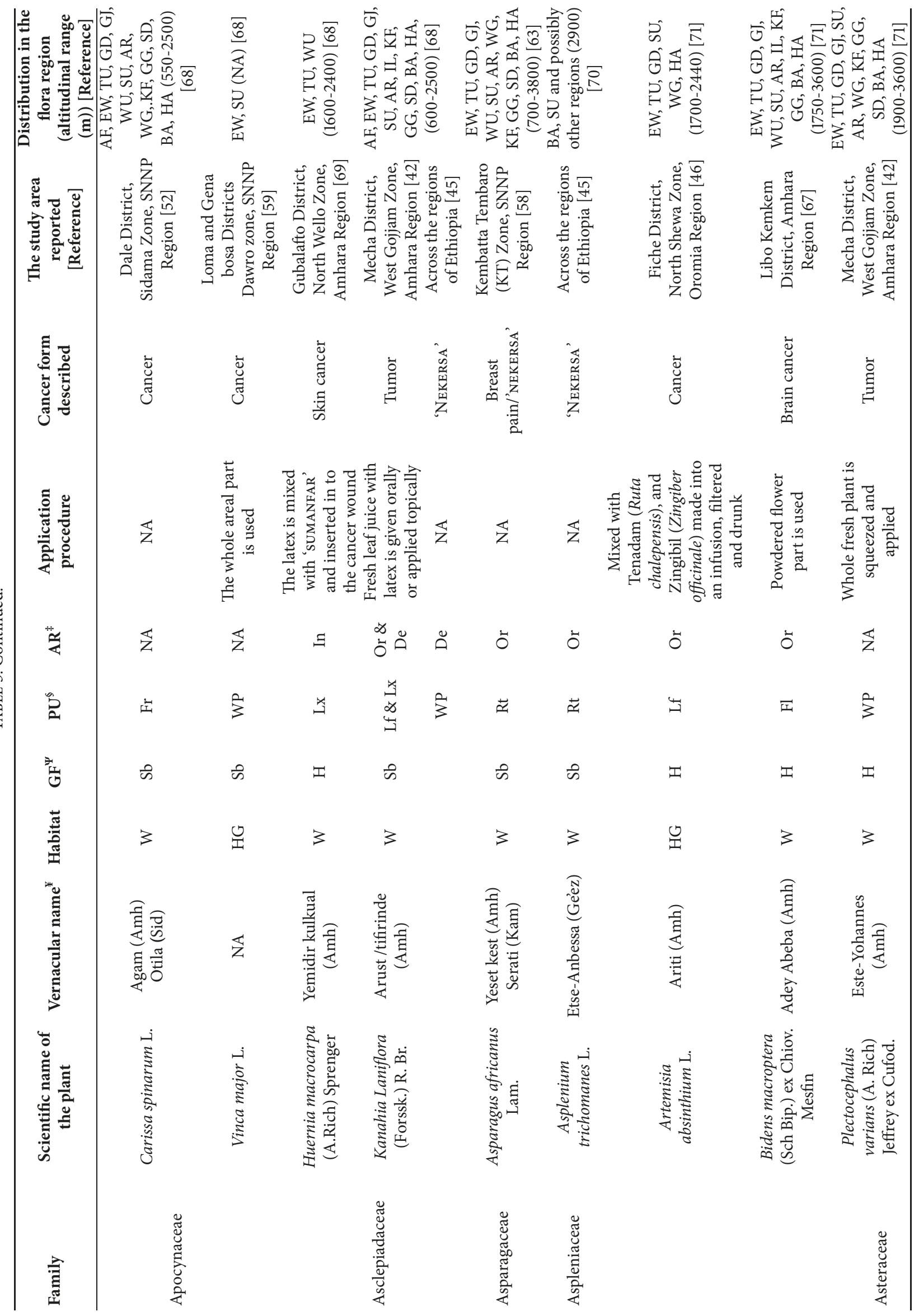




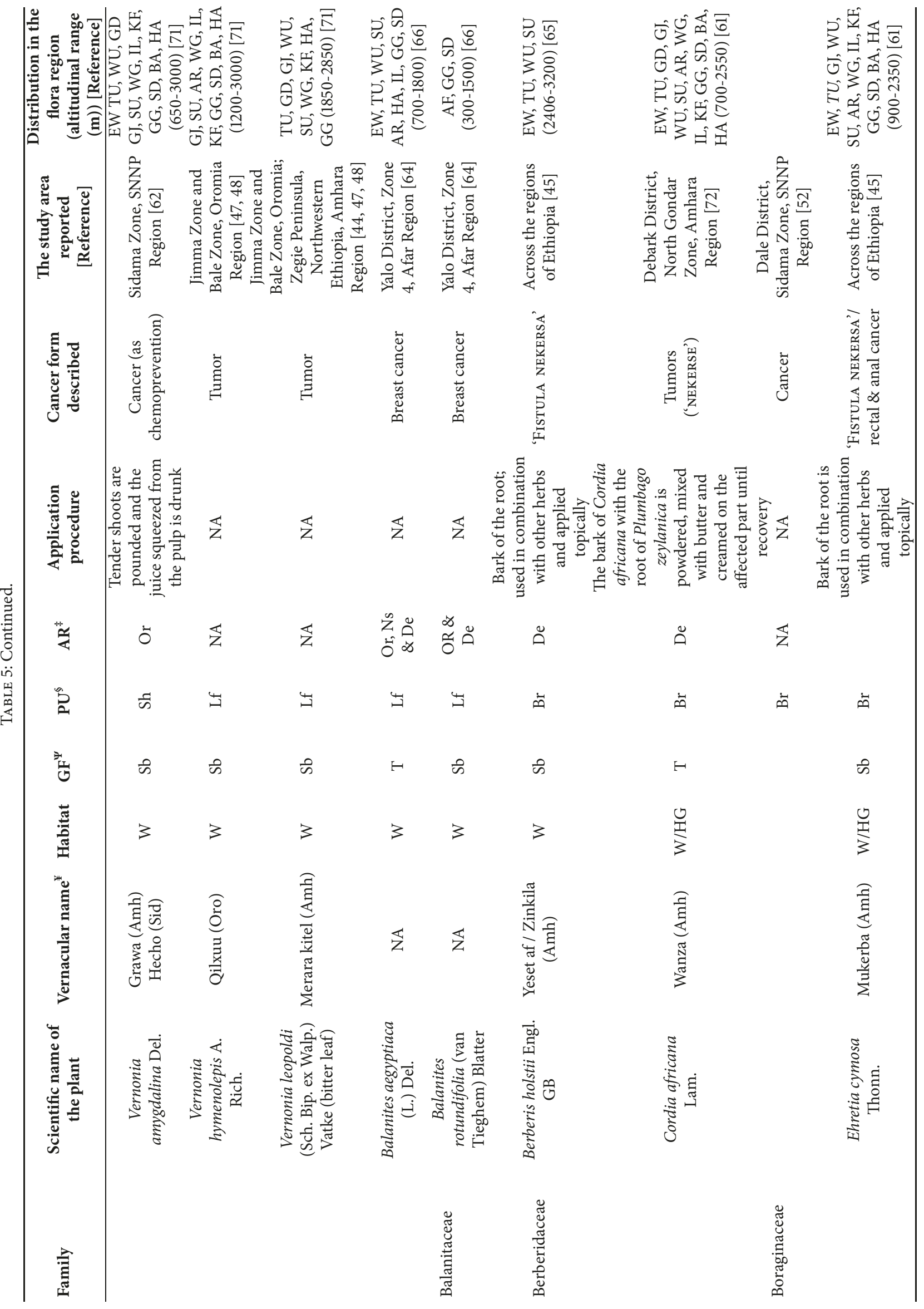




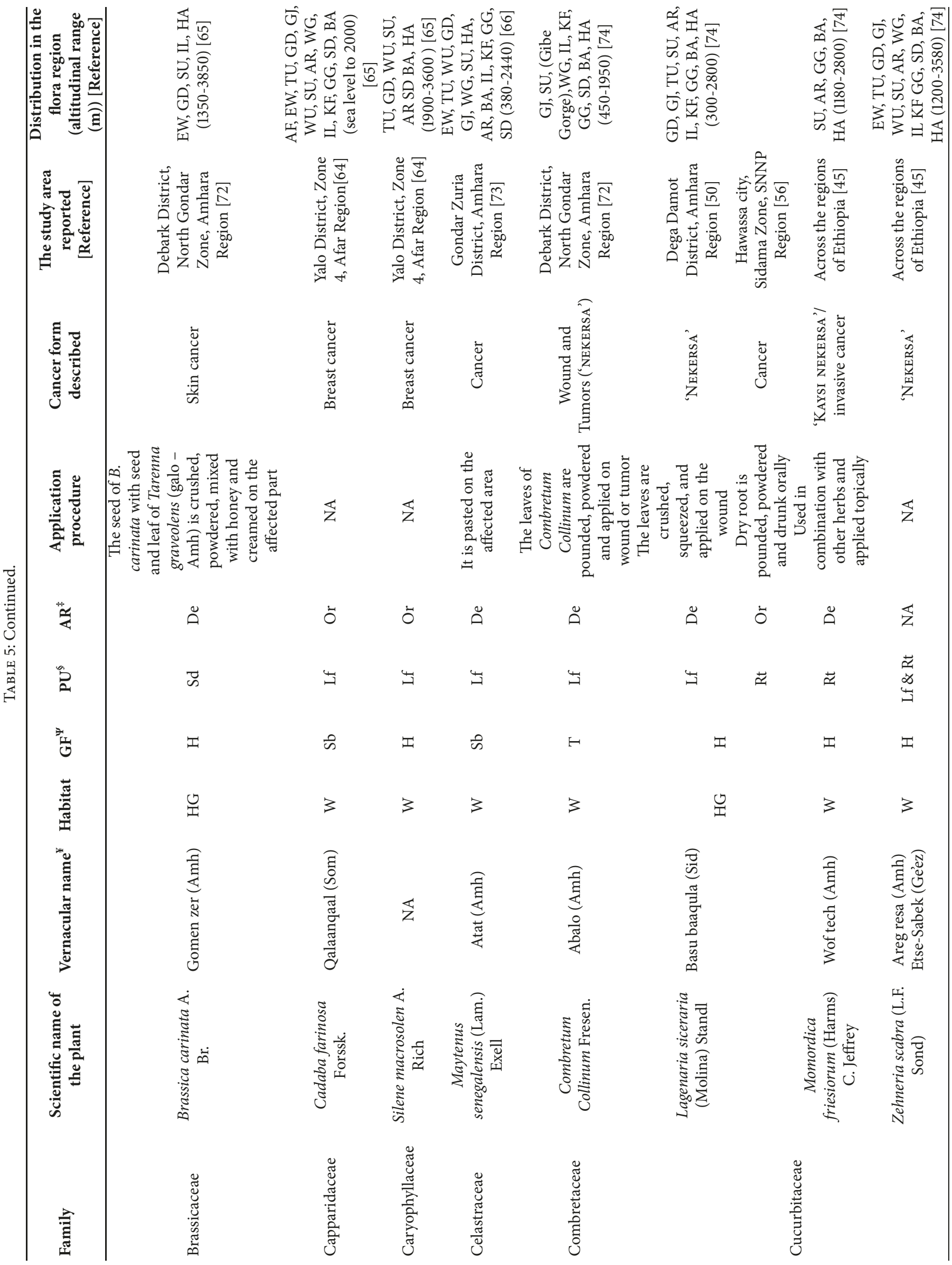




\begin{tabular}{|c|c|c|c|c|c|c|c|c|c|}
\hline 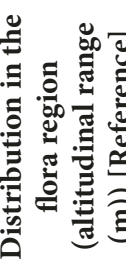 & 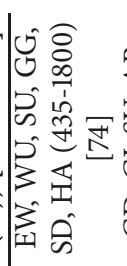 & 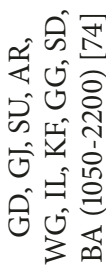 & 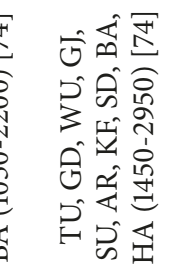 & & 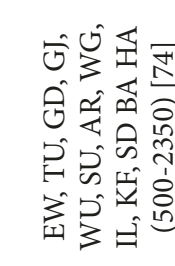 & & 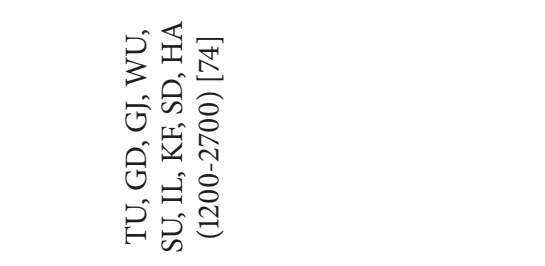 & 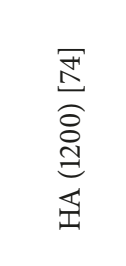 & 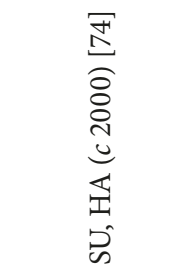 \\
\hline 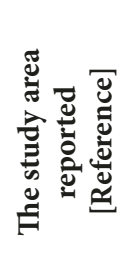 & 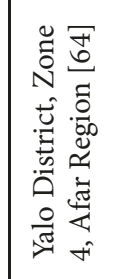 & 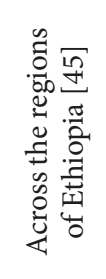 & 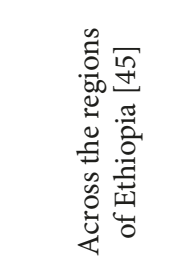 & 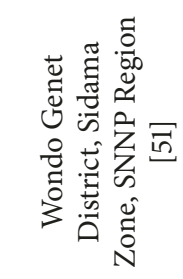 & 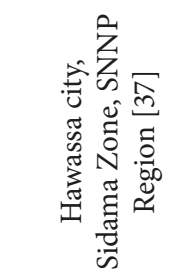 & 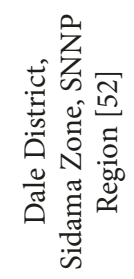 & 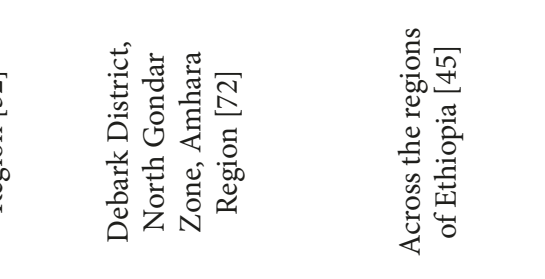 & 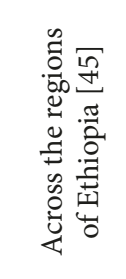 & 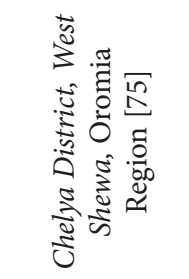 \\
\hline 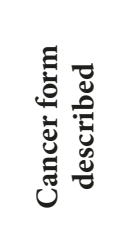 & 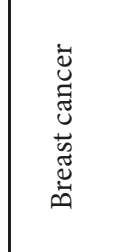 & 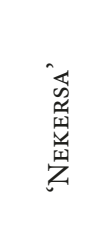 & 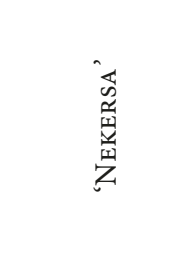 & 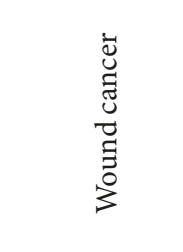 & 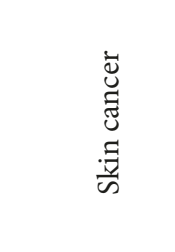 & $\begin{array}{l}\ddot{\tilde{u}} \\
\text { ज̃ }\end{array}$ & 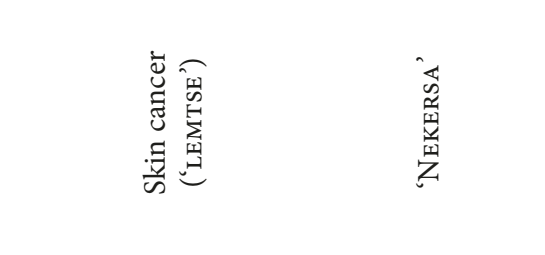 & 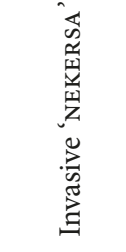 & 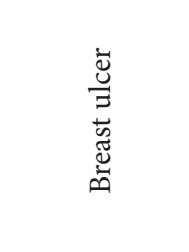 \\
\hline 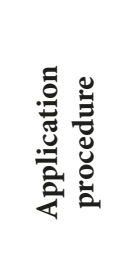 & 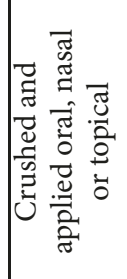 & $\overleftrightarrow{z}$ & 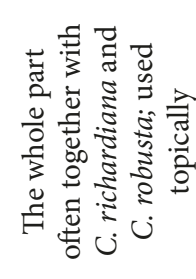 & 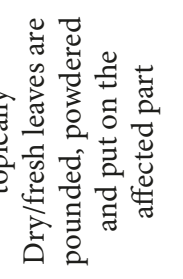 & 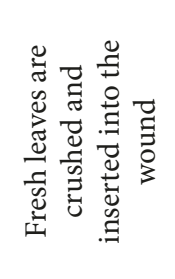 & $\overleftrightarrow{z}$ & 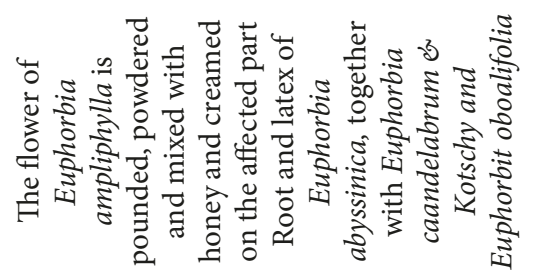 & $\overleftrightarrow{z}$ & 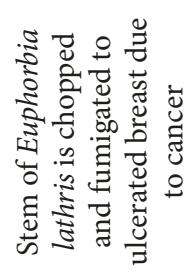 \\
\hline 華 & $\begin{array}{l}\ddot{z} \tilde{~} \\
\tilde{0} \infty\end{array}$ & $\overleftrightarrow{z}$ & ๑ & ฉ & $\Xi$ & $\overleftrightarrow{z}$ & $\overleftrightarrow{z}$ & $\overleftrightarrow{z}$ & ڤั \\
\hline s & 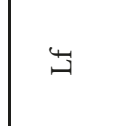 & $\ddot{\approx}$ & $\xi_{3}^{2}$ & 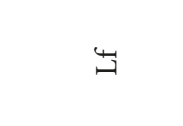 & 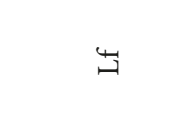 & 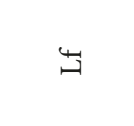 & 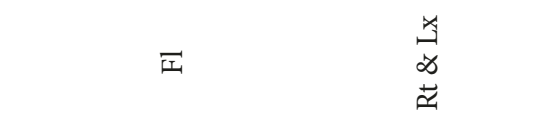 & 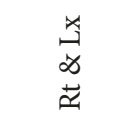 & $\ddot{\omega}$ \\
\hline 至 & के & के & I & के & & & $\mathrm{H}$ & क & 工 \\
\hline 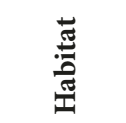 & 3 & 3 & 3 & 3 & & & 3 & 3 & ن \\
\hline 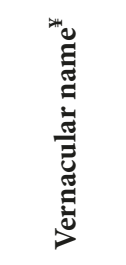 & $\overleftrightarrow{z}$ & 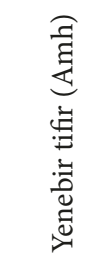 & 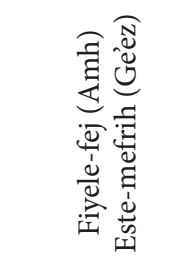 & 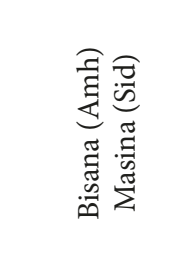 & & & 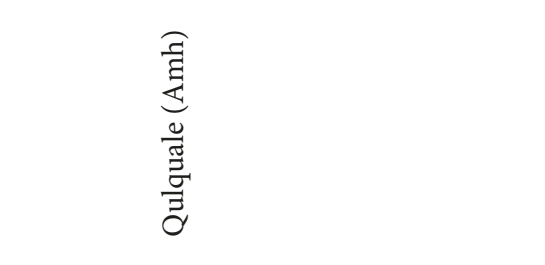 & 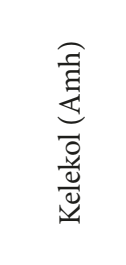 & 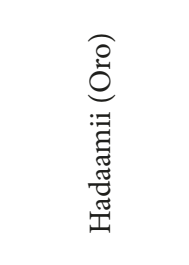 \\
\hline 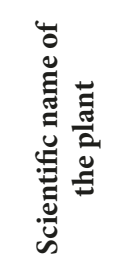 & 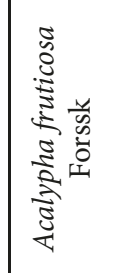 & 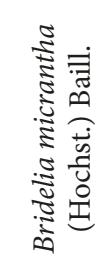 & 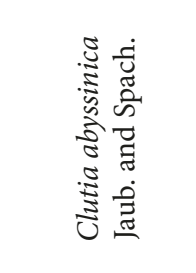 & 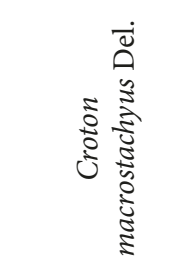 & & & 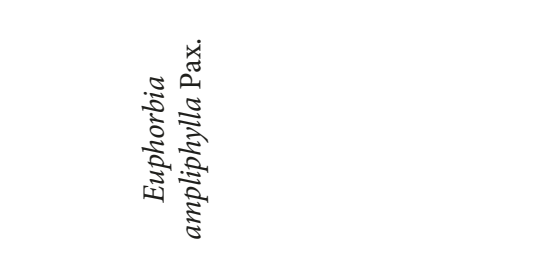 & 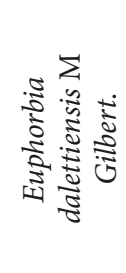 & 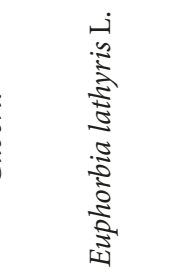 \\
\hline 츨 & & & & & & & 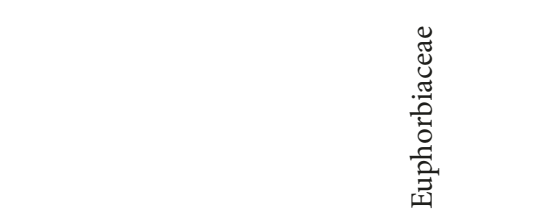 & & \\
\hline
\end{tabular}




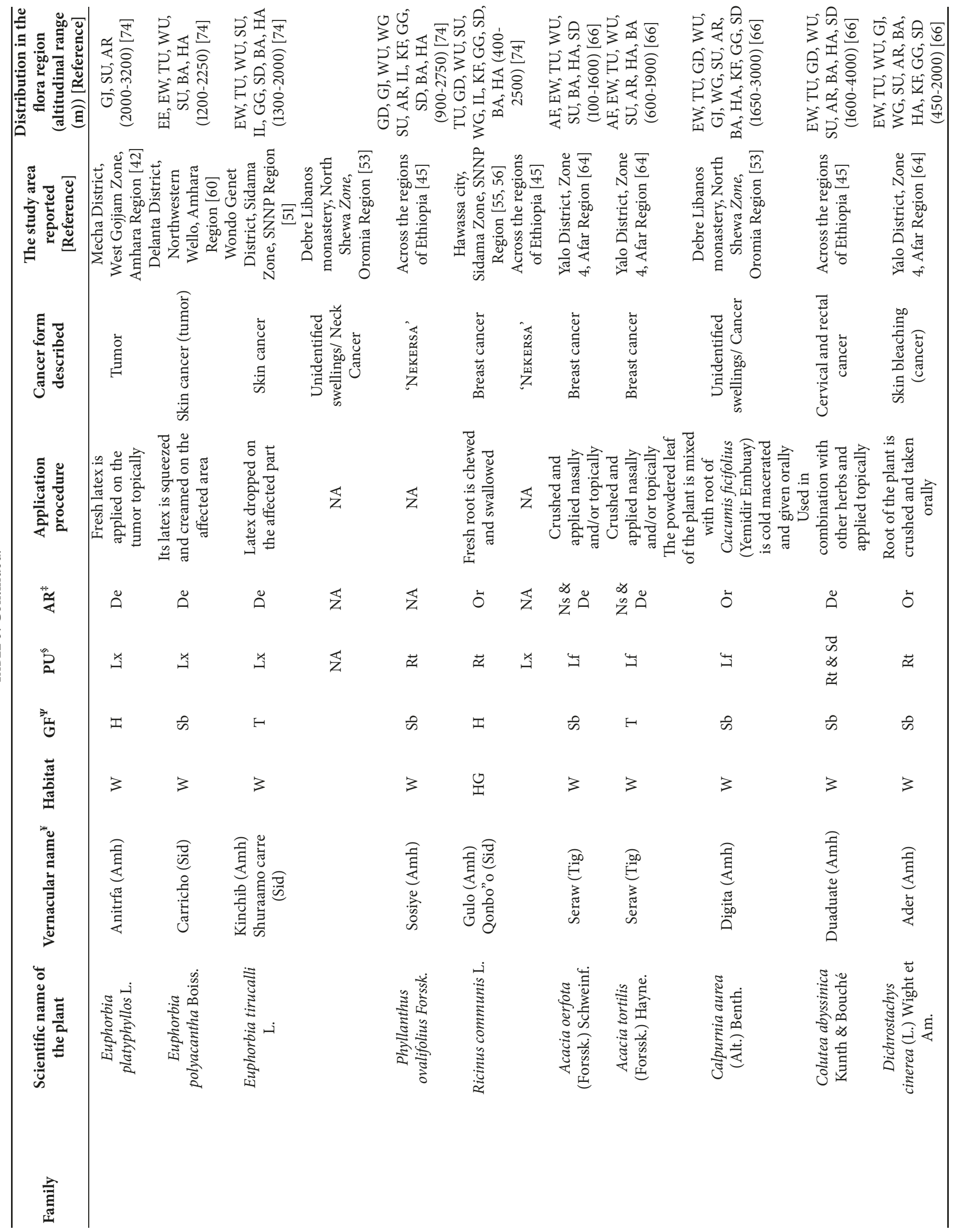




\begin{tabular}{|c|c|c|c|c|c|c|c|c|c|c|c|c|}
\hline 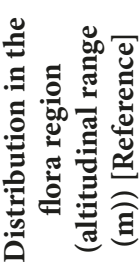 & 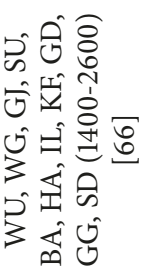 & 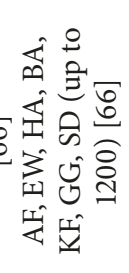 & 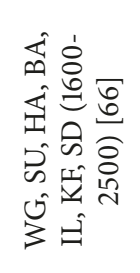 & 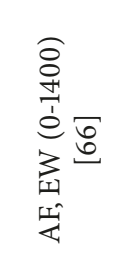 & 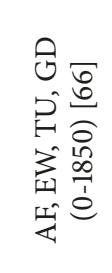 & 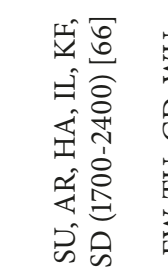 & 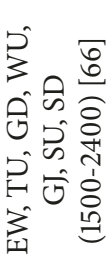 & 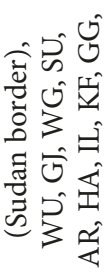 & & 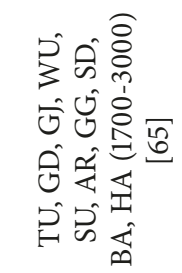 & & 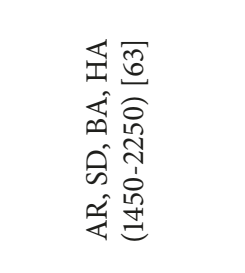 \\
\hline 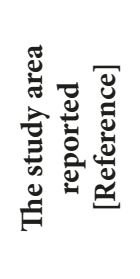 & 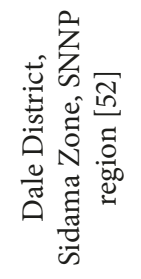 & 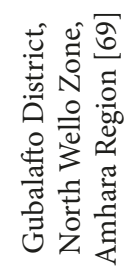 & 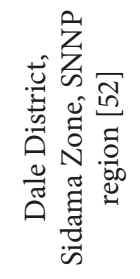 & 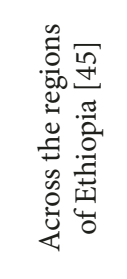 & 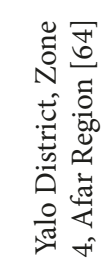 & 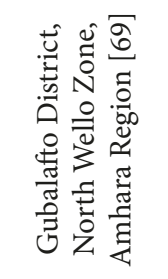 & 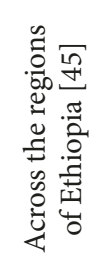 & 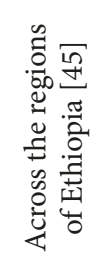 & 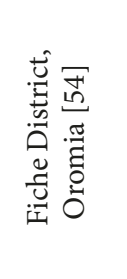 & 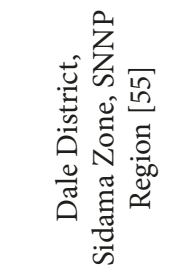 & 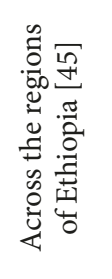 & 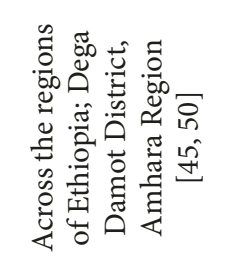 \\
\hline 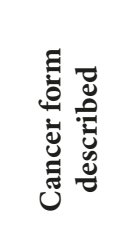 & 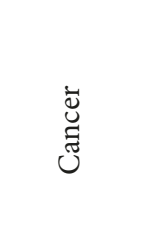 & 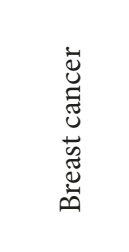 & 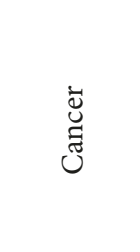 & 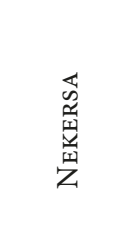 & 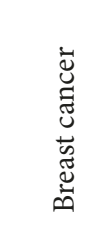 & 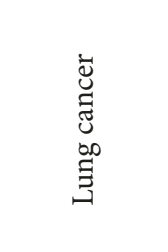 & 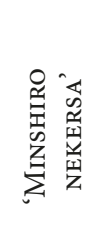 & 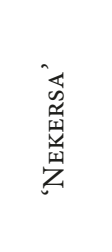 & $\begin{array}{l}\breve{\Xi} \\
\tilde{J}\end{array}$ & 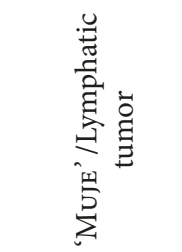 & 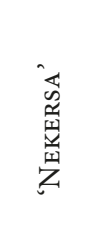 & 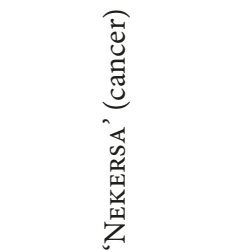 \\
\hline 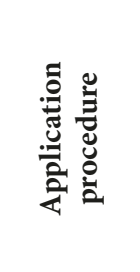 & $\overleftrightarrow{z}$ & 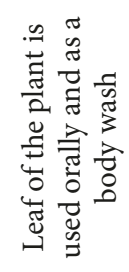 & 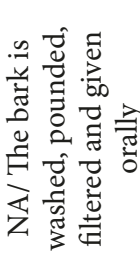 & 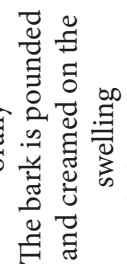 & 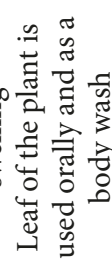 & 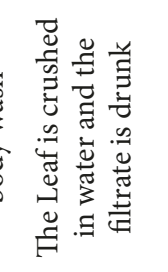 & 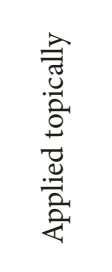 & $\overleftrightarrow{\mathrm{z}}$ & 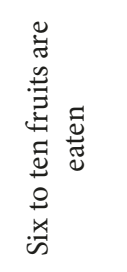 & 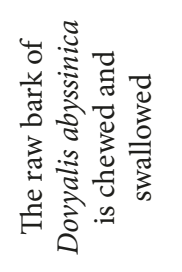 & 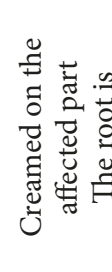 & 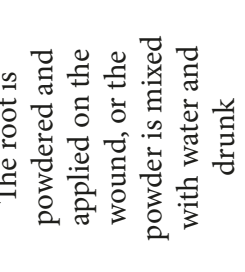 \\
\hline 蒙 & $\overleftrightarrow{z}$ & $\begin{array}{l}\varnothing \\
\check{0}\end{array}$ & ŏ & $\tilde{\Omega}$ & 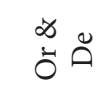 & $\check{o}$ & ค̆ & $\overleftrightarrow{z}$ & $\ddot{o}$ & ö & $\tilde{a}$ & 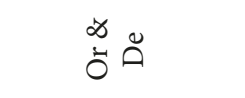 \\
\hline 点 & $\ddot{n}$ & 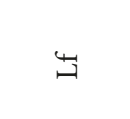 & $\ddot{n}$ & $\ddot{n}$ & 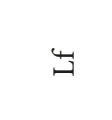 & 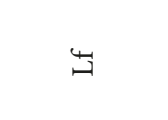 & 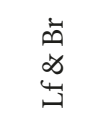 & $\ddot{\approx}$ & 宅 & $\vec{n}$ & $\xi$ & $\ddot{\simeq}$ \\
\hline 焉 & $H$ & क & $H$ & क & I & 工 & के & के & क & & & I \\
\hline 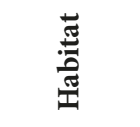 & 3 & 3 & 3 & 3 & 3 & 3 & 3 & 3 & 3 & & & 3 \\
\hline 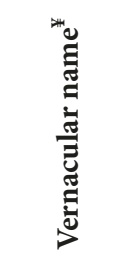 & 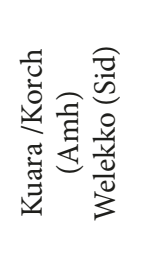 & $\overleftrightarrow{z}$ & 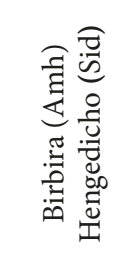 & 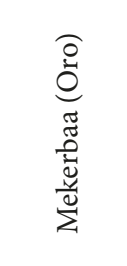 & $\overleftrightarrow{z}$ & $\overleftrightarrow{Z}$ & 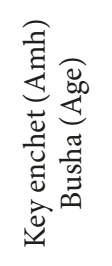 & 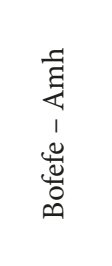 & 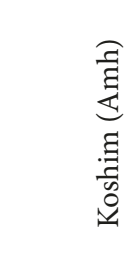 & & & 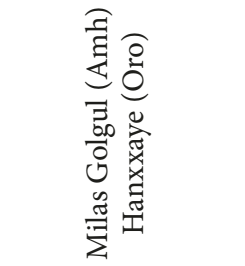 \\
\hline 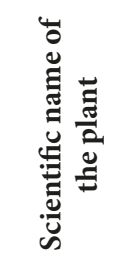 & 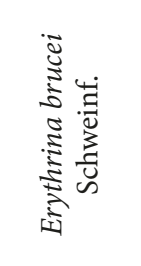 & 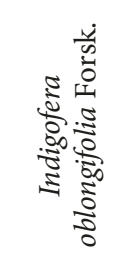 & 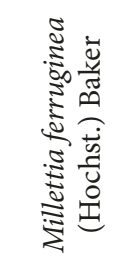 & 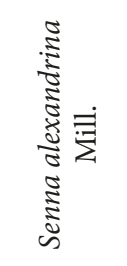 & 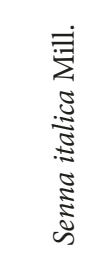 & 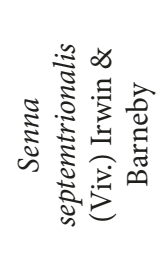 & 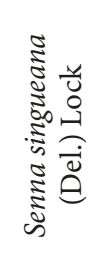 & 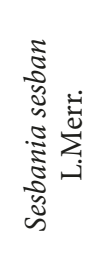 & 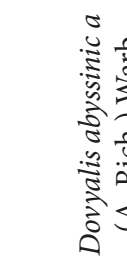 & & & 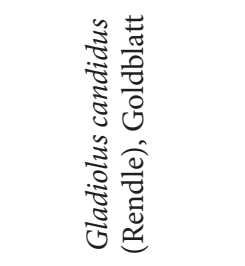 \\
\hline 昰 & & & & & & & & & 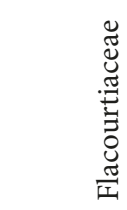 & & & $\begin{array}{l}\stackrel{\Xi}{\Xi} \\
\stackrel{\Xi}{\Xi} \\
\stackrel{\Xi}{\Xi}\end{array}$ \\
\hline
\end{tabular}




\begin{tabular}{|c|c|c|c|c|c|c|c|c|c|c|}
\hline 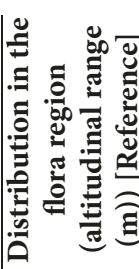 & 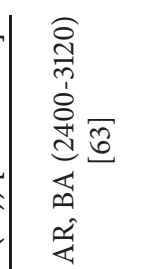 & 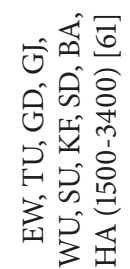 & 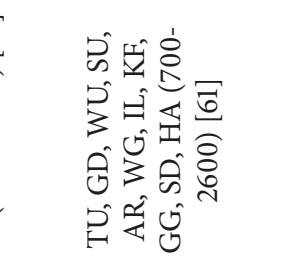 & 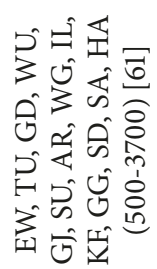 & 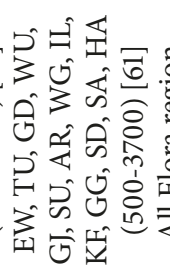 & 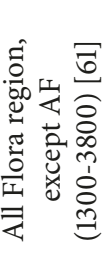 & 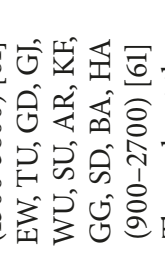 & 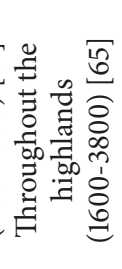 & 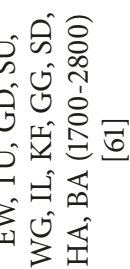 & 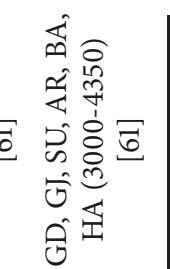 \\
\hline 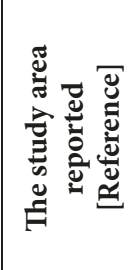 & 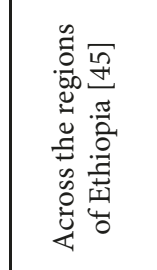 & 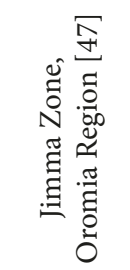 & 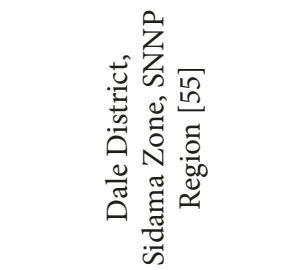 & 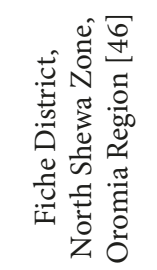 & 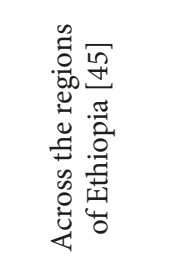 & 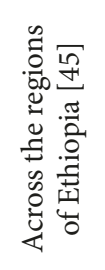 & 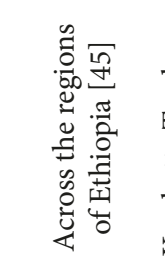 & 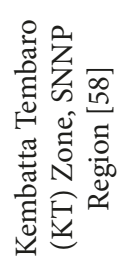 & 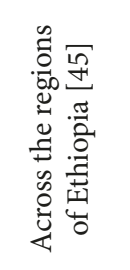 & 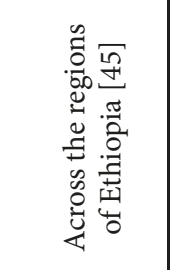 \\
\hline 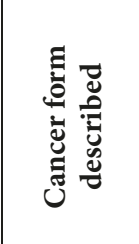 & 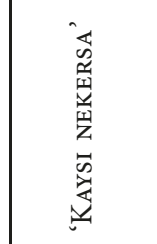 & 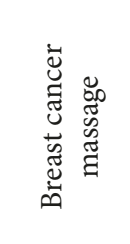 & 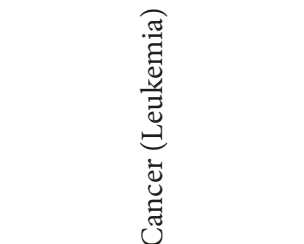 & 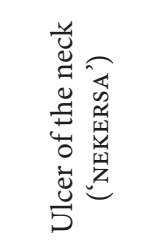 & 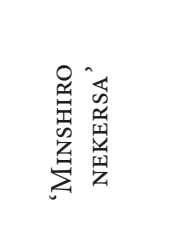 & 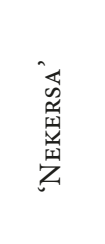 & 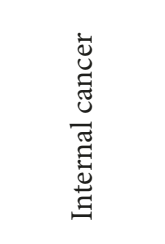 & 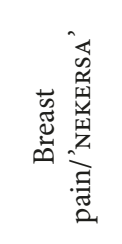 & 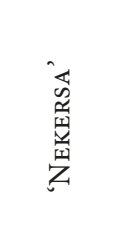 & 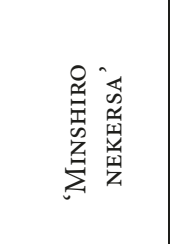 \\
\hline 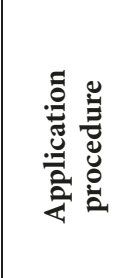 & 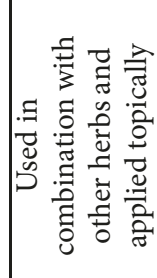 & 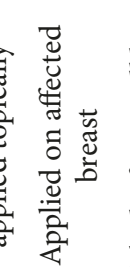 & 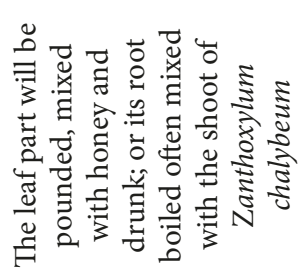 & 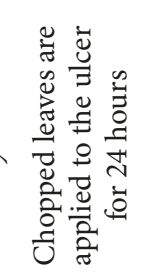 & 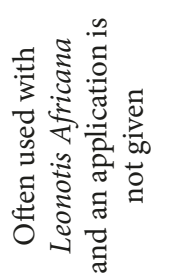 & $\overleftrightarrow{z}$ & 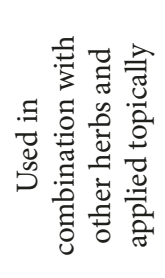 & $\widetilde{z}$ & 㐏 & 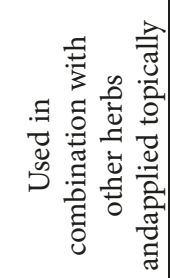 \\
\hline 莚 & ฉั & ฉั & ప & $\check{D}$ & $\overleftrightarrow{z}$ & $\overleftrightarrow{z}$ & $\check{\circ}$ & ة & $\mathbb{z}$ & ฉั \\
\hline s & $\ddot{\approx}$ & $\Psi$ & $\Psi$ & 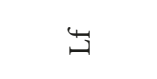 & $\ddot{\approx}$ & $\ddot{夭}$ & 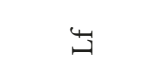 & $\vec{w}$ & $\stackrel{\nexists \unlhd}{\exists}$ & $\overrightarrow{\widetilde{q}}$ \\
\hline 密 & I & 麦 & I & के & के & I & के & I & $\mathrm{H}$ & \\
\hline 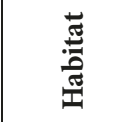 & 3 & 3 & 3 & 3 & 3 & 3 & 3 & 选 & 3 & \\
\hline 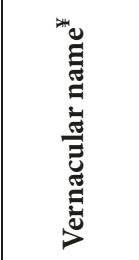 & 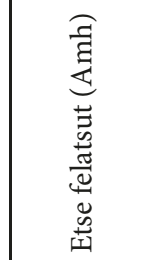 & 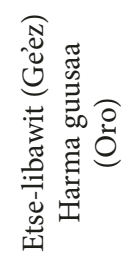 & 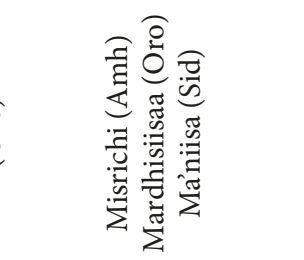 & 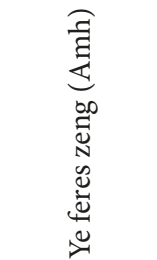 & 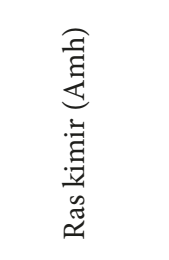 & 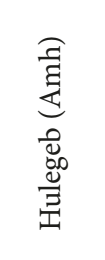 & 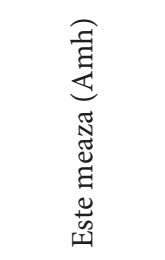 & 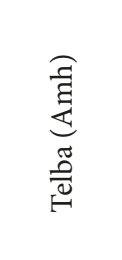 & 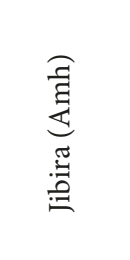 & 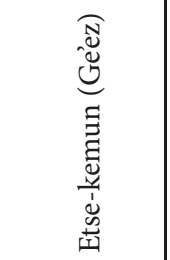 \\
\hline 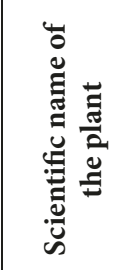 & 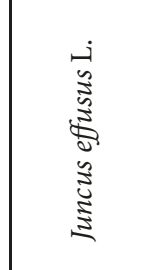 & 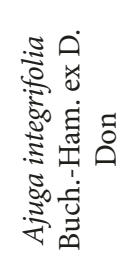 & 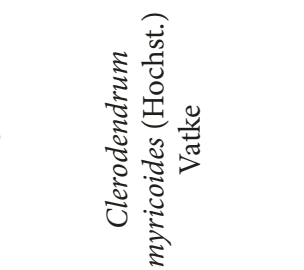 & 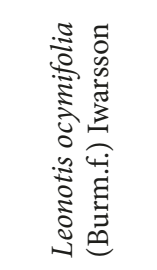 & 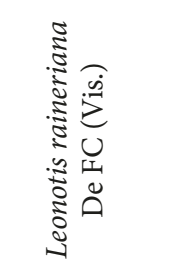 & 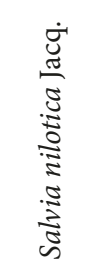 & 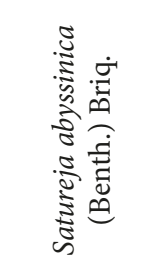 & 羙章 & 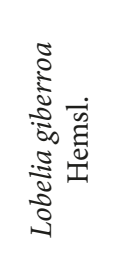 & 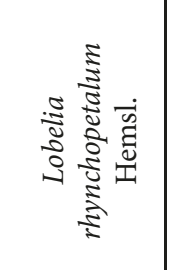 \\
\hline 量 & 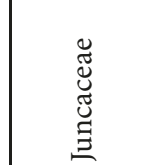 & & & 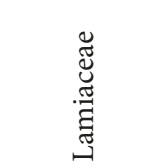 & & & & 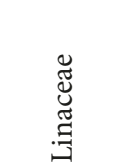 & 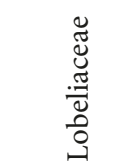 & \\
\hline
\end{tabular}




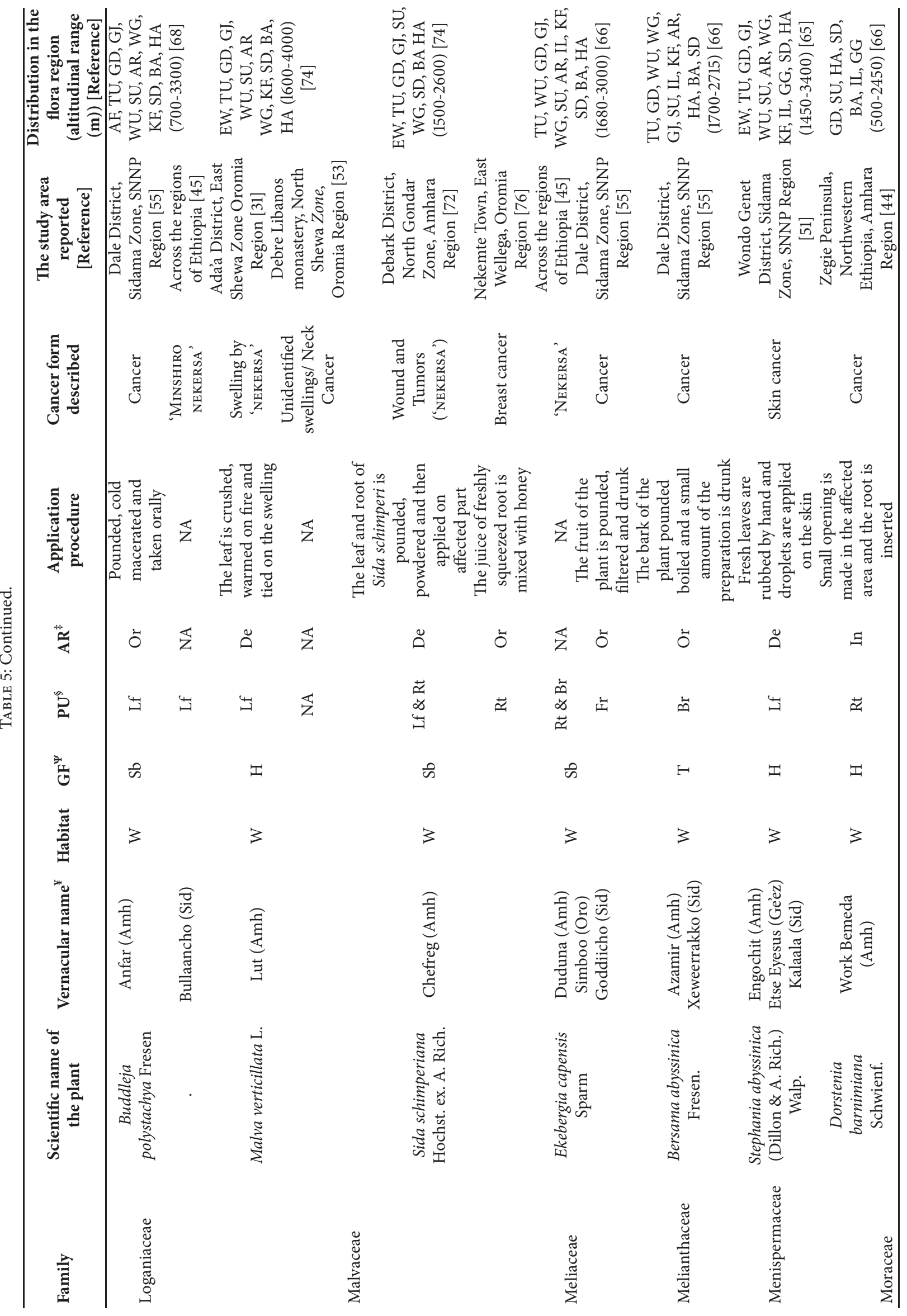




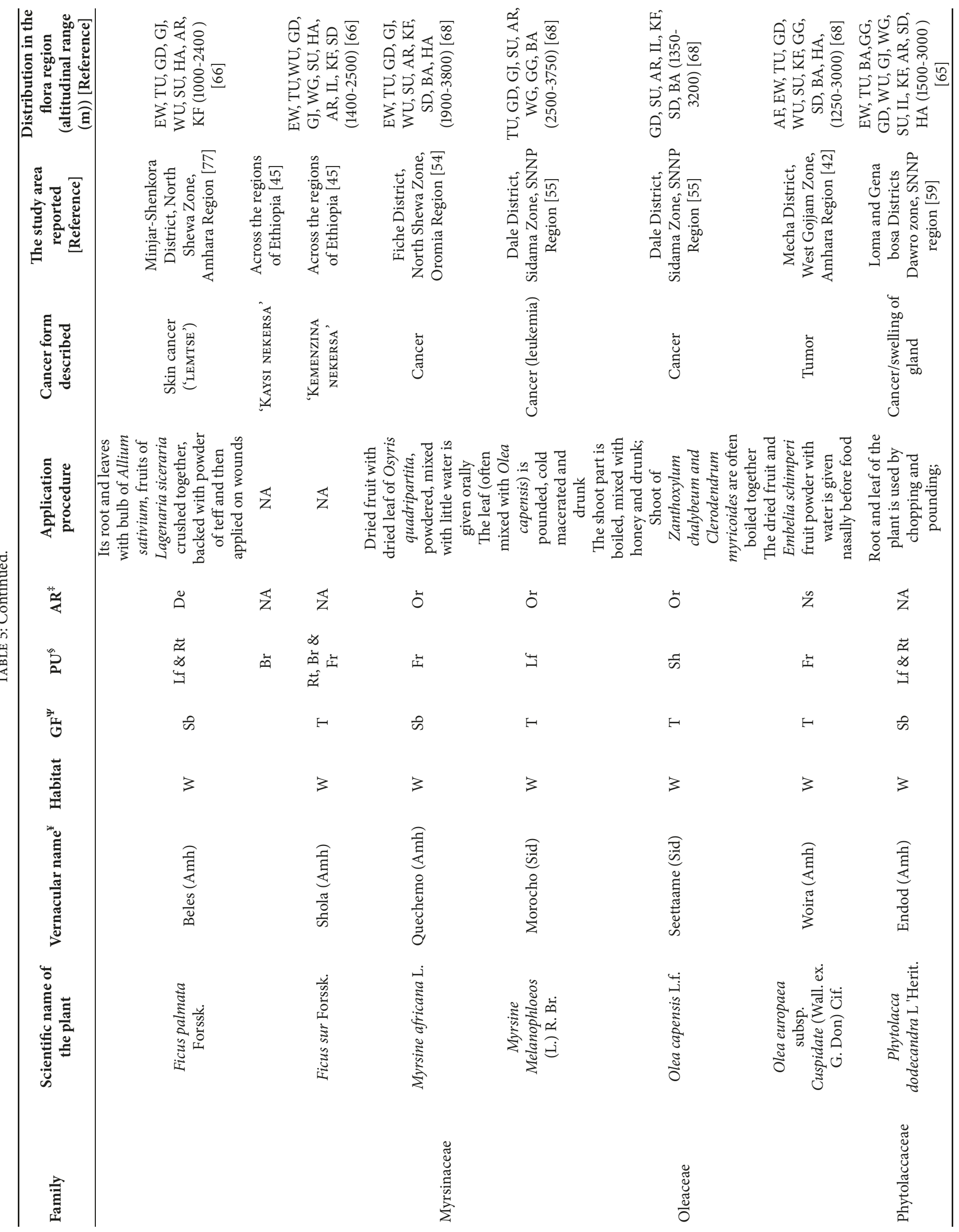




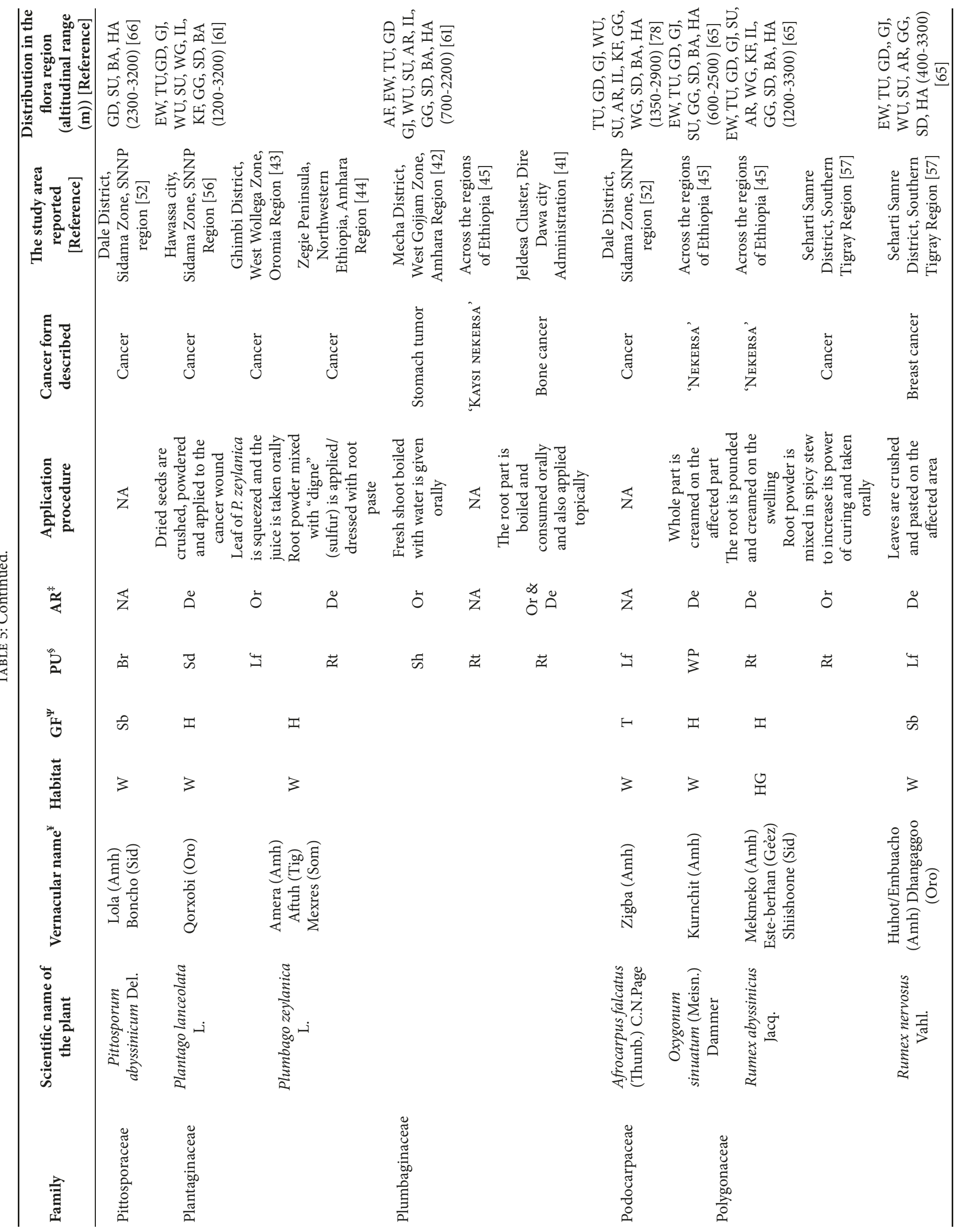




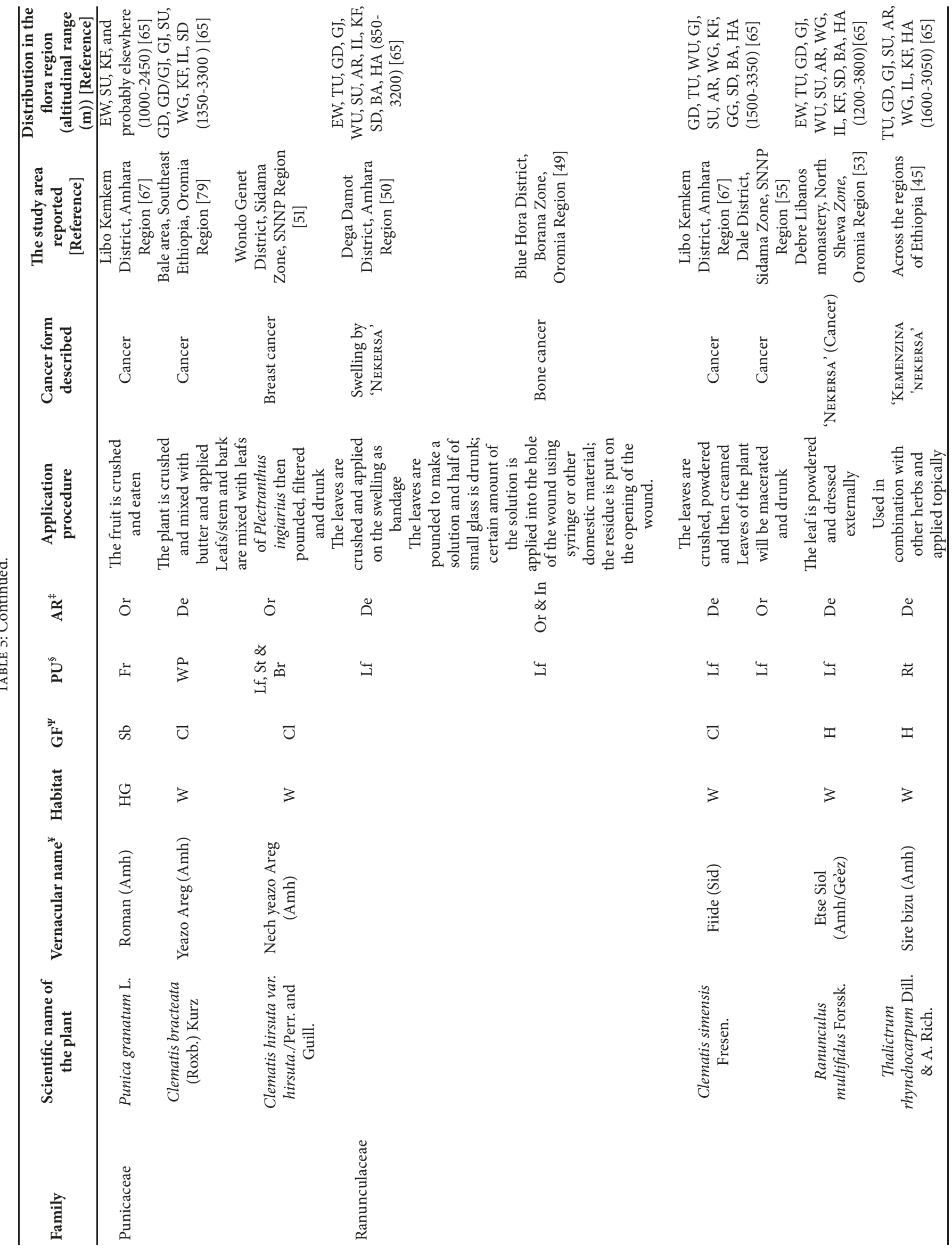




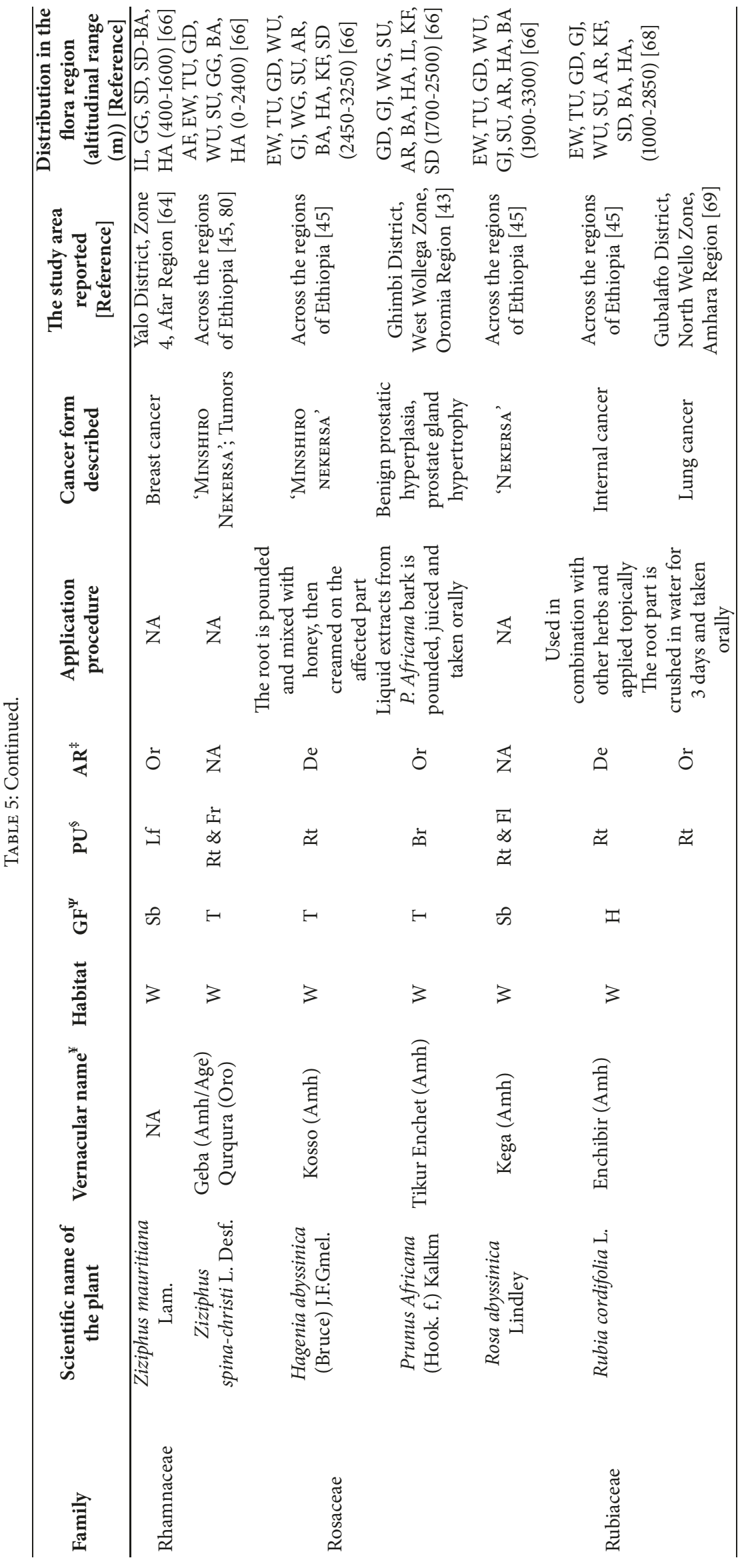




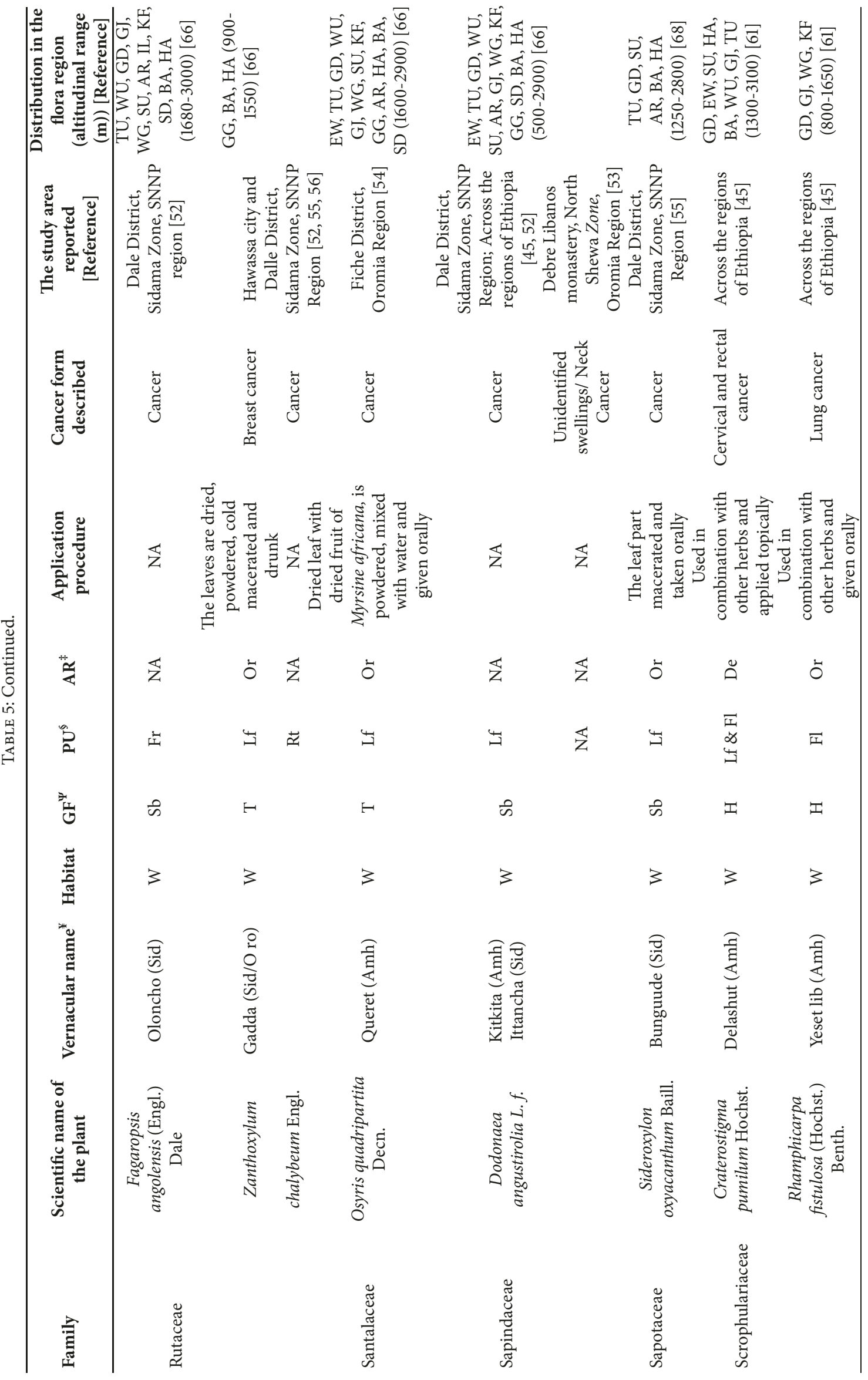




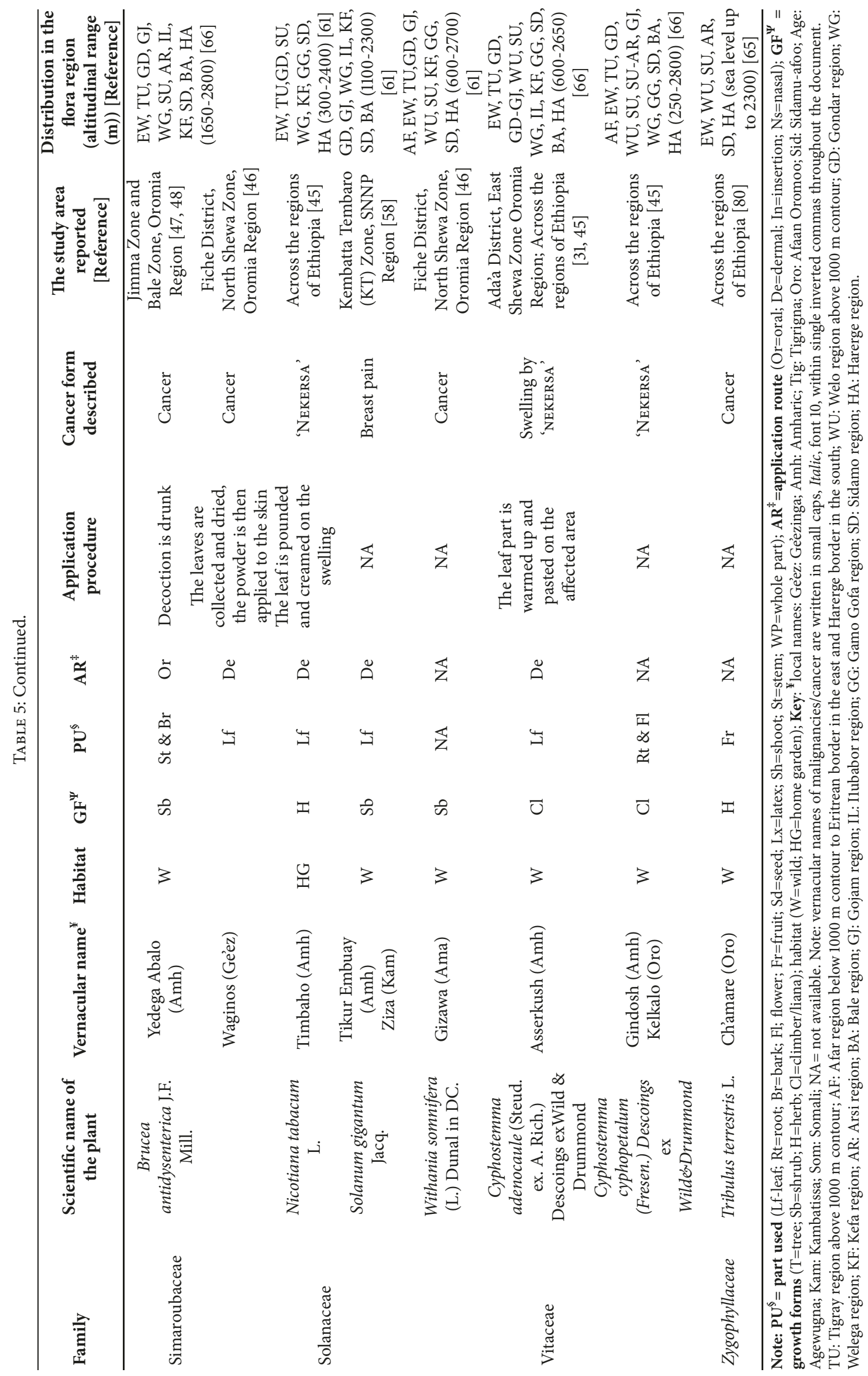


manuscript. All authors have read, approved, and agreed on submission of the final manuscript.

\section{Acknowledgments}

The authors would like to appreciate Mr. Girma Gudesho, lecturer at Mizan-Tepi University and a Ph.D. candidate at AAU, for kindly generating the map shown in Figure 2 using ArcGIS.

\section{References}

[1] J. S. Long and K. M. Ryan, "New frontiers in promoting tumour cell death: Targeting apoptosis, necroptosis and autophagy," Oncogene, vol. 31, no. 49, pp. 5045-5060, 2012.

[2] J. Font-Burgada, B. Sun, and M. Karin, "Obesity and Cancer: The Oil that Feeds the Flame," Cell Metabolism, vol. 23, no. 1, pp. 48-62, 2016.

[3] L. A. Torre, F. Bray, R. L. Siegel, J. Ferlay, and J. LortetTieulent, "Global cancer statistics, 2012," CA: A Cancer Journal for Clinicians, vol. 65, no. 2, pp. 87-108, 2015.

[4] WHO: Fact sheet No. 297: Cancer. http://www.who.int/mediacentre/factsheets/fs297/en/.

[5] WHO, Global Health Risks: Mortality and Burden of Disease Attributable to Selected Major Risks, World Health Organization, 2009.

[6] A. Jemal, F. Bray, D. Forman et al., "Cancer burden in Africa and opportunities for prevention," Cancer, vol. 118, no. 18, pp. 4372-4384, 2012.

[7] V. A. McCormack and J. Schüz, "Africa's growing cancer burden: Environmental and occupational contributions," Cancer Epidemiology, vol. 36, no. 1, pp. 1-7, 2012.

[8] D. M. Parkin, F. Bray, J. Ferlay, and A. Jemal, "Cancer in Africa 2012," Cancer Epidemiology, Biomarkers \& Prevention, vol. 23, no. 6, pp. 953-966, 2014.

[9] E. Weiderpass, "Lifestyle and cancer risk," Journal of Preventive Medicine \& Public Health, vol. 43, no. 6, pp. 459-471, 2010.

[10] J. Ferlay, H. R. Shin, F. Bray, D. Forman, C. Mathers, and D. M. Parkin, "Estimates of worldwide burden of cancer in 2008: GLOBOCAN 2008," International Journal of Cancer, vol. 127, no. 12, pp. 2893-2917, 2010.

[11] Y. W. Woldeamanuel, B. Girma, and A. M. Teklu, "Cancer in Ethiopia," The Lancet Oncology, vol. 14, no. 4, pp. 289-290, 2013.

[12] T. Hailu, H. Berhe, and D. Hailu, "Awareness of Breast Cancer and Its Early Detection Measures among Female Students, Northern Ethiopia," International Journal of Public Health Science (IJPHS), vol. 5, no. 3, p. 213, 2016.

[13] B. Legesse and T. Gedif, "Knowledge on breast cancer and its prevention among women household heads in Northern Ethiopia," Open Journal of Preventive Medicine, vol. 04, no. 01, pp. 32-40, 2014.

[14] N. Yarom, E. Gorbatsevich, N. Geva et al., "Colon cancer in immigrants from Ethiopia.," Journal of Clinical Oncology, vol. 33, no. 3_suppl, pp. 521-521, 2015.

[15] WHO, Cancer Country Profiles, World Health Organization, 2014.

[16] M. Assefa, Assessment of types and treatment pattern of cancer in TASH Radiotherapy Center: Retrospective study [M.Sc. thesis], Addis Ababa University, Addis Ababa, 2011.
[17] H. Ma, C. L. Carpenter, J. Sullivan-Halley, and L. Bernstein, "The roles of herbal remedies in survival and quality of life among long-term breast cancer survivors - results of a prospective study," BMC Cancer, vol. 11, article no. 222, 2011.

[18] WHO, WHO traditional medicine strategy 2014-2023, World Health Organization, Geneva, 2013.

[19] O. Olaku and J. D. White, "Herbal therapy use by cancer patients: a literature review on case reports," European Journal of Cancer, vol. 47, no. 4, pp. 508-514, 2011.

[20] D. Sakarkar and V. Deshmukh, "Ethnopharmacological review of traditional medicinal plants for anticancer activity," International Journal of PharmTech Research, vol. 3, no. 1, pp. 298-308, 2011.

[21] J. Vardy, H. M. Dhillon, S. J. Clarke et al., "Investigation of herb-drug interactions with ginkgo biloba in women receiving hormonal treatment for early breast cancer," SpringerPlus, vol. 2, no. 1, p. 126, 2013.

[22] M. A. Richardson, L. C. Mâsse, K. Nanny, and C. Sanders, "Discrepant views of oncologists and cancer patients on complementary/ alternative medicine," Supportive Care in Cancer, vol. 12, no. 11, pp. 797-804, 2004.

[23] X. Li, G. Yang, Y. Zhang et al., "Traditional Chinese medicine in cancer care: a review of controlled clinical studies published in Chinese," PLoS ONE, vol. 8, no. 4, Article ID e60338, 2013.

[24] A. Molassiotis, P. Fernandez-Ortega, D. Pud et al., "Use of complementary and alternative medicine in cancer patients: a European survey," Annals of Oncology, vol. 16, no. 4, pp. 655663, 2005.

[25] E. Ernst, "The prevalence of complementary/alternative medicine in cancer: a systematic review," Cancer, vol. 83, no. 4, pp. 777-782, 1998.

[26] D. . M Malki, Cancer Treatment Strategies, OMICS International, 2014.

[27] D. O. Levitsky and V. M. Dembitsky, "Anti-breast Cancer Agents Derived from Plants," Natural Products and Bioprospecting, vol. 5, no. 1, pp. 1-16, 2015.

[28] F. Kibebew, "The Status of Availability of Data of Oral and Written Knowledge and Traditional Health Care in Ethiopia," in Conservation and Sustainable Use of Medicinal Plants in Ethiopia, pp. 107-119, Institute of Biodiversity Conservation and Research, Addis Ababa, 2001.

[29] A. Debela, D. Abebe, and K. Urga, "An over view of traditional medicine in Ethiopia: perspective and developmental efforts," Ethiopian Pharmaceutical Association, vol. 72, pp. 45-52, 1999.

[30] L. M. Souza, T. C. Boone, and J. Gabrilove, "Recombinant human granulocyte colony-stimulating factor: effects on normal and leukemic myeloid cells," Science, vol. 232, no. 4746, pp. 61-65, 1986.

[31] A. Kefalew, Z. Asfaw, and E. Kelbessa, "Ethnobotany of medicinal plants in Ada'a District, East Shewa Zone of Oromia Regional State, Ethiopia," Journal of Ethnobiology and Ethnomedicine, vol. 11, article 25, 2015.

[32] T. Awas, M. Gashaw, and G. Tesfaye, Ecosystems of Ethiopia. in. National Biodiversity Strategy and Action Plan (NBSAP) Project, Ethiopia, Addis Ababa, IBCR, 2003.

[33] IBCR, Convention on Biological Diversity (CBD) Ethiopias 4th Country Report, IBC, Addis Ababa, Ethiopia, 2009.

[34] Hydro Meteorological Bulletin for May, 2016, Addis Ababa, http://www.ethiomet.gov.et/bulletins/bulletins.

[35] T. B. Gebre-Egziabher, "Diversity of Ethiopian flora," in Plant Genetic resources of Ethiopia, Engels J. M. M., J. G. Hawkes, 
and M. Worede, Eds., p. 75, Cambridge University Press, Cambridge, 1991.

[36] E. Kelbessa, S. Demissew, and Z. Woldu, "Some threatened endemic plants of Ethiopia," The status of some plants in parts of tropical Africa, pp. 35-55, 1992.

[37] R. Regassa, "Diversity and conservation status of some economically valued indigenous medicinal plants in Hawassa College of Teacher Education Campus, Southern Ethiopia," International Journal of Advanced Research, vol. 1, no. 3, pp. 308-328, 2013.

[38] E. Kelbessa and S. Demissew, "Diversity of vascular plant taxa of the flora of Ethiopia and Eritrea," The Ethiopian Journal of Biological Sciences, vol. 13, pp. 37-45, 2014.

[39] R. Tena, Endemic Medicinal Plants of Ethiopia: Review of the Literature [Ph.D. thesis], Addis Ababa University, 2014.

[40] E. Bekele, Study on actual situation of medicinal plants in Ethiopia, Prepared for Japan Association for International Collaboration of Agriculture and Forestry (JAICAF), Addis Abab.

[41] A. Shimels, K. Atinafu, M. Akalu, and M. Getachew, "Ethnobotanical study of medicinal plants used by agro pastoralist Somali people for the management of human ailments in Jeldesa Cluster, Dire Dawa Administration, Eastern Ethiopia," Journal of Medicinal Plants Research, vol. 11, no. 9, pp. 171-187, 2017.

[42] G. Gebeyehu, Z. Asfaw, and A. Enyew, "Ethnobotanical study of traditional medicinal plants and their conservation status in Mecha Woreda, West Gojjam Zone of Ethiopia," International Journal of Pharmaceuticals and Health care Research, vol. 2, p. $17,2014$.

[43] B. Abera, "Medicinal plants used in traditional medicine by Oromo people, Ghimbi District, Southwest Ethiopia," Journal of Ethnobiology and Ethnomedicine, vol. 10, no. 1, article 40, 2014.

[44] T. Teklehaymanot and M. Giday, "Ethnobotanical study of medicinal plants used by people in Zegie Peninsula, Northwestern Ethiopia," Journal of Ethnobiology and Ethnomedicine, vol. 3, article 12, 2007.

[45] G. Abate, in Etse Debdabe - Ethiopian traditional medicine (Amharic version), S. Demissew, Ed., Addis Ababa University, Addis Ababa, Ethiopia, 1989.

[46] E. d'Avigdor, H. Wohlmuth, Z. Asfaw, and T. Awas, "The current status of knowledge of herbal medicine and medicinal plants in Fiche, Ethiopia," Journal of Ethnobiology and Ethnomedicine, vol. 10, no. 1, pp. 38-71, 2014.

[47] B. Abera, "Medicinal plants used in traditional medicine in Jimma Zone," Ethiopian Journal of Health Development, vol. 13, no. 2, 2003.

[48] N. T. Wabe, M. A. Mohammed, and N. J. Raju, "An ethnobotanical survey of medicinal plants in the Southeast Ethiopia used in traditional medicine," Spatula DD, vol. 1, no. 3, pp. 153-158, 2011.

[49] M. A. Eshete, Ethnobotanical Study of Medicinal Plants in Guji Agro-pastorilists, Bule Hora District of Borana Zone, Oromia Region, Ethiopia [M.Sc. thesis], Addis Ababa University, 2011.

[50] L. Limenih, S. Umer, and M. Wolde-Mariam, "Ethnobotanical Study on Traditional Medicinal Plants in Dega Damot Woreda, Amhara Region, North Ethiopia," International Journal of Research in Pharmacy and Chemistry, vol. 5, pp. 258-273, 2015.

[51] S. T. Beyene, An Ethnobotanical Study of Medicinal Plants in Wondo Genet Natural Forest and Adjacent Kebeles, Sidama Zone, SNNP Region, Ethiopia [M.Sc. thesis], Addis Ababa University, 2011.
[52] G. Kewessa, T. Abebe, and A. Demessie, "Indigenous knowledge on the use and management of medicinal trees and shrubs in Dale District, Sidama Zone, Southern Ethiopia," Ethnobotany Research and Applications, vol. 14, pp. 171-182, 2015.

[53] T. Teklehaymanot, M. Giday, G. Medhin, and Y. Mekonnen, "Knowledge and use of medicinal plants by people around Debre Libanos monastery in Ethiopia," Journal of Ethnopharmacology, vol. 111, no. 2, pp. 271-283, 2007.

[54] A. Enyew, Z. Asfaw, E. Kelbessa et al., "Ethnobotanical study of traditional medicinal plants in and around Fiche District," Current Research Journal of Biological Sciences, vol. 6, no. 4, pp. 154-167, 2014.

[55] N. Tuasha, B. Petros, and Z. Asfaw, "Medicinal plants used by traditional healers to treat malignancies and other human ailments in Dalle District, Sidama Zone, Ethiopia," Journal of Ethnobiology and Ethnomedicine, vol. 14, no. 1, 2018.

[56] R. Regassa, "Assessment of indigenous knowledge of medicinal plant practice and mode of service delivery in Hawassa city, southern Ethiopia," Journal of Medicinal Plants Research, vol. 7, no. 9, pp. 517-535, 2013.

[57] S. Araya, B. Abera, and M. Giday, "Study of plants traditionally used in public and animal health management in Seharti Samre District, Southern Tigray, Ethiopia," Journal of Ethnobiology and Ethnomedicine, vol. 11, no. 1, article no. 22, 2015.

[58] M. Maryo, S. Nemomissa, and T. Bekele, "An ethnobotanical study of medicinal plants of the Kembatta ethnic group in Enset-based agricultural landscape of Kembatta Tembaro (KT) Zone, Southern Ethiopia," Asian Journal of Plant Science Research, vol. 5, no. 7, pp. 42-61, 2015.

[59] M. Agize, S. Demissew, and Z. Asfaw, "Ethnobotany of medicinal plants in Loma and Gena bosa districts (woredas) of dawro zone, southern Ethiopia," Topclass Journal of Herbal Medicine, vol. 2, pp. 194-212, 2013.

[60] M. Meragiaw, Z. Asfaw, and M. Argaw, "The Status of Ethnobotanical Knowledge of Medicinal Plants and the Impacts of Resettlement in Delanta, Northwestern Wello, Northern Ethiopia," Evidence-Based Complementary and Alternative Medicine, vol. 2016, Article ID 5060247, 24 pages, 2016.

[61] I. Hedberg, Flora of Ethiopia and Eritrea, vol. 5, Uppsala: The National Herbarium, Addis Ababa, Ethiopia, and Department of Systematic Botany, 2006.

[62] H. T. G. Busse, "Handbook of Sidama Traditional Medicinal Plants," in A Service Learning Project School of Medicine and Public Health, University of Wisconsin Madison (UW), 2013.

[63] R. Schmid, S. Edwards, S. Demissew, and I. Hedberg, "Flora of Ethiopia and Eritrea," in Hydrocharitaceae to Arecaceae, vol. 6, Uppsala: The National Herbarium, Addis Ababa, Ethiopia, and Department of Systematic Botany, 1997.

[64] T. Teklehaymanot, "An ethnobotanical survey of medicinal and edible plants of Yalo Woreda in Afar regional state, Ethiopia," Journal of Ethnobiology and Ethnomedicine, vol. 13, no. 1, 2017.

[65] S. Edwards, M. Tadesse, S. Demissew, and I. Hedberg, "Flora of Ethiopia and Eritrea," in Magnoliaceae to Flacourtiaceae., Uppsala, The National Herbarium, vol. 2, Uppsala: The National Herbarium, Addis Ababa, Ethiopia, and Department of Systematic Botany, 2000.

[66] I. Hedberg and S. Edwards, Flora of Ethiopia, volume 3: Pittosporaceae to Araliaceae: The National Herbarium, Uppsala: Addis Ababa, Ethiopia, and Department of Systematic Botany, 1989.

[67] G. Chekole, Z. Asfaw, and E. Kelbessa, "Ethnobotanical study of medicinal plants in the environs of Tara-gedam and Amba 
remnant forests of Libo Kemkem District, northwest Ethiopia," Journal of Ethnobiology and Ethnomedicine, vol. 11, no. 1, 2015.

[68] I. Hedberg, S. Edwards, and S. Nemomissa, Flora of Ethiopia and Eritrea. Volume 4, part 1. Apiaceae to Dipsacaceae, Uppsala: The National Herbarium, Addis Ababa, Ethiopia, and Department of Systematic Botany, 2003.

[69] G. Chekole, "Ethnobotanical study of medicinal plants used against human ailments in Gubalafto District, Northern Ethiopia," Journal of Ethnobiology and Ethnomedicine, vol. 13, no. 1, article 55, 2017.

[70] P. Chaerle and R. Viane, "Additions to the fern flora of Ethiopia," Willdenowia, vol. 32, no. 1, pp. 55-60, 2002.

[71] I. Hedberg, I. Friis, and S. Edwards, Flora of Ethiopia and Eritrea. Volume 4, part 2. Asteraceae, Uppsala: The National Herbarium, Addis Ababa, Ethiopia, and Department of Systematic Botany, 2004.

[72] E. Abebe, Ethnobotanical Study on Medicinal Plants Used by Local Communities in Debark Wereda, North Gondar Zone, Amhara Regional State, Ethiopia [M.Sc. thesis], Addis Ababa University, 2011.

[73] Z. Birhanu, "Traditional use of medicinal plants by the ethnic groups of Gondar Zuria district, North-Western Ethiopia," Journal of Natural Remedies, vol. 13, no. 1, pp. 46-53, 2013.

[74] S. Edwards, M. Tadesse, and I. Hedberg, Flora of Ethiopia and Eritrea, volume 2, part 2: Canellaceae to Euphorbiaceae, Uppsala: The National Herbarium, Addis Ababa, Ethiopia, and Department of Systematic Botany, 1995.

[75] E. Amenu, Use and management of medicinal plants by indigenous people of Ejaji area (chelya woreda) west shoa, Ethiopia: An ethnobotanical approach [M.Sc. thesis], Addis Ababa University, Ethiopia, 2007.

[76] S. Suleman and T. Alemu, "A survey on utilization of ethnomedicinal plants in Nekemte town, East Wellega (Oromia), Ethiopia," Journal of Herbs, Spices \& Medicinal Plants, vol. 18, no. 1, pp. 34-57, 2012.

[77] G. Alemayehu, Ethnobotanical Study on Medicinal Plants Used by Indigenous Local Communities in Minjar-Shenkora Wereda, North Shewa Zone of Amhara Region, Ethiopia [M.Sc. thesis], Addis Ababa University, 2010.

[78] I. Friis, "Floristic richness and endemism in the flora of Ethiopia and Eritrea," in Flora of Ethiopia and Eritrea, volume 8 General part and index to volumes 1-7, I. Hedberg, I. Friis, and E. Presson, Eds., The National Herbarium, Addis Ababa, Ethiopia, and Department of Systematic Botany, Uppsala, Sweden, 2009.

[79] R. W. Bussmann, P. Swartzinsky, A. Worede, and P. Evangelista, "Plant use in Odo-Bulu and Demaro, Bale region, Ethiopia," Journal of Ethnobiology and Ethnomedicine, vol. 7, article 28, 2011.

[80] R. Yadav, "Medicinal plants in folk medicine system of Ethiopia," Journal of Poisonous and Medicinal Plants Research, vol. 1, no. 1, p. 11, 2013.

[81] H. P. Freeman and K. C. Chu, "Determinants of cancer disparities: Barriers to cancer screening, diagnosis, and treatment," Surgical Oncology Clinics of North America, vol. 14, no. 4, pp. 655-669, 2005.

[82] A. Jemal, R. Siegel, E. Ward et al., "Cancer statistics, 2008," CA: A Cancer Journal for Clinicians, vol. 58, no. 2, pp. 71-96, 2008.

[83] H. J. Wanebo, B. J. Kennedy, J. Chmiel, G. Steele Jr., D. Winchester, and R. Osteen, "Cancer of the stomach. A patient care study by the American college of surgeons," Annals of Surgery, vol. 218, no. 5, pp. 583-592, 1993.
[84] M. Sant, C. Allemani, R. Capocaccia et al., "Stage at diagnosis is a key explanation of differences in breast cancer survival across Europe," International Journal of Cancer, vol. 106, no. 3, pp. 416422, 2003.

[85] J. J. G. Marin, R. Al-Abdulla, E. Lozano et al., "Mechanisms of resistance to chemotherapy in gastric cancer," Anti-Cancer Agents in Medicinal Chemistry, vol. 16, no. 3, pp. 318-334, 2016.

[86] E. Harlev, E. Nevo, E. Solowey, and A. Bishayee, "Cancer preventive and curative attributes of plants of the Cactaceae family: A review," Planta Medica, vol. 79, no. 9, pp. 713-722, 2013.

[87] J. D. McChesney, S. K. Venkataraman, and J. T. Henri, "Plant natural products: Back to the future or into extinction?" Phytochemistry, vol. 68, no. 14, pp. 2015-2022, 2007.

[88] M. Giday, Z. Asfaw, Z. Woldu, and T. Teklehaymanot, "Medicinal plant knowledge of the Bench ethnic group of Ethiopia: an ethnobotanical investigation," Journal of Ethnobiology and Ethnomedicine, vol. 5, article 34, 2009.

[89] F. Senbeta, T. Woldemariam Gole, M. Denich, and E. Kellbessa, "Diversity of useful plants in the coffee forests of Ethiopia," Ethnobotany Research and Applications, vol. 11, pp. 49-70, 2013.

[90] T. Awas and S. Demissew, "Ethnobotanical study of medicinal plants in Kafficho people, southwestern Ethiopia," in Proceedings of the 16th International Conference of Ethiopian Studies, pp. 711-726, 2009.

[91] M. Ragunathan and S. M. Abay, "Ethnomedicinal survey of folk drugs used in Bahirdar Zuria district, Northwestern Ethiopia," Indian Journal of Traditional Knowledge, vol. 8, no. 2, pp. 281284, 2009.

[92] G. Yirga, M. Teferi, and M. Kasaye, "Survey of medicinal plants used to treat human ailments in Hawzen district, Northern Ethiopia," International Journal of Biodiversity and Conservation, vol. 3, no. 13, pp. 709-714, 2011.

[93] T. Seta, S. Demissew, and Z. Asfaw, "Home gardens of Wolayta, Southern Ethiopia. An ethnobotanical profile," Academia Journal of Medicinal Plants, vol. 1, no. 1, pp. 14-30, 2013.

[94] M. A. Seid and S. G. Aydagnehum, "Medicinal plants biodiversity and local Healthcare management system in Chencha District; Gamo Gofa, Ethiopia," Journal of Pharmacognosy and Phytochemistry, vol. 2, no. 1, pp. 284-293, 2013.

[95] S. Zerabruk and G. Yirga, "Traditional knowledge of medicinal plants in Gindeberet district, Western Ethiopia," South African Journal of Botany, vol. 78, pp. 165-169, 2012.

[96] M. Gebrehiwot, An Ethnobotanical Study of Medicinal Plants in Seru Wereda, Arsi Zone of Oromia Region, Ethiopia [M.Sc. thesis], Addis Ababa University, 2010.

[97] H. Yineger and D. Yewhalaw, "Traditional medicinal plant knowledge and use by local healers in Sekoru District, Jimma Zone, Southwestern Ethiopia," Journal of Ethnobiology and Ethnomedicine, vol. 3, article 24, 2007.

[98] M. Bekele, Ethnobotanical Study of Medicinal Plants in Gorichei Wereda, Sidama Zone, SNNPR, Ethiopia [M.Sc. thesis], Addis Ababa University, 2014.

[99] S. Asnake, T. Teklehaymanot, A. Hymete, B. Erko, and M. Giday, "Survey of Medicinal Plants Used to Treat Malaria by Sidama People of Boricha District, Sidama Zone, South Region of Ethiopia," Evidence-Based Complementary and Alternative Medicine, vol. 2016, 2016.

[100] D. Moher, A. Liberati, J. Tetzlaff, and D. G. Altman, "Preferred reporting items for systematic reviews and meta-analyses: the PRISMA statement," PLoS Medicine, vol. 6, no. 7, Article ID e1000097, 2009. 
[101] T. Awas, "Endemic plants of Ethiopia: Preliminary working list to contribute to National plant conservation target," Institute of Biodiversity Conservation, p. 14, 2016.

[102] E. Dagne, Natural Database for Africa(NDA), CD-ROM Version 2.0, Addis Ababa, Ethiopia, 2011.

[103] A. Belayneh and N. F. Bussa, "Ethnomedicinal plants used to treat human ailments in the prehistoric place of Harla and Dengego valleys, eastern Ethiopia," Journal of Ethnobiology and Ethnomedicine, vol. 10, article 18, 2014.

[104] W. Birhan, M. Giday, and T. Teklehaymanot, "The contribution of traditional healers' clinics to public health care system in Addis Ababa, Ethiopia: a cross-sectional study," Journal of Ethnobiology and Ethnomedicine, vol. 7, article 39, 2011.

[105] K. Tolossa, E. Debela, S. Athanasiadou, A. Tolera, G. Ganga, and J. G. M. Houdijk, "Ethno-medicinal study of plants used for treatment of human and livestock ailments by traditional healers in South Omo, Southern Ethiopia," Journal of Ethnobiology and Ethnomedicine, vol. 9, no. 1, article no. 32, 2013.

[106] A. Teklay, B. Abera, and M. Giday, "An ethnobotanical study of medicinal plants used in Kilte Awulaelo district, Tigray Region of Ethiopia," Journal of Ethnobiology and Ethnomedicine, vol. 9, no. 1, article 65, 2013.

[107] E. Lulekal, E. Kelbessa, T. Bekele, and H. Yineger, "An ethnobotanical study of medicinal plants in Mana Angetu District, southeastern Ethiopia," Journal of Ethnobiology and Ethnomedicine, vol. 4, article 10, 2008.

[108] F. Mesfin, S. Demissew, and T. Teklehaymanot, "An ethnobotanical study of medicinal plants in Wonago Woreda, SNNPR, Ethiopia," Journal of Ethnobiology and Ethnomedicine, vol. 5, no. 28, 2009.

[109] T. H. Bekalo, S. D. Woodmatas, and Z. A. Woldemariam, "An ethnobotanical study of medicinal plants used by local people in the lowlands of Konta Special Woreda, southern nations, nationalities and peoples regional state, Ethiopia," Journal of Ethnobiology and Ethnomedicine, vol. 5, article 26, 2009.

[110] M. Giday, Z. Asfaw, and Z. Woldu, "Medicinal plants of the Meinit ethnic group of Ethiopia: an ethnobotanical study," Journal of Ethnopharmacology, vol. 124, no. 3, pp. 513-521, 2009.

[111] M. Megersa, Z. Asfaw, E. Kelbessa, A. Beyene, and B. Woldeab, "An ethnobotanical study of medicinal plants in Wayu Tuka District, East Welega Zone of Oromia Regional State, West Ethiopia," Journal of Ethnobiology and Ethnomedicine, vol. 9, article 68, 2013.

[112] B. Assefa, G. Glatzel, and C. Buchmann, "Ethnomedicinal uses of Hagenia abyssinica (Bruce) J.F. Gmel. among rural communities of Ethiopia," Journal of Ethnobiology and Ethnomedicine, vol. 6, article no. 20, 2010.

[113] S. Kebede, M. Afework, A. Debella, W. Ergete, and E. Makonnen, "Toxicological study of the butanol fractionated root extract of Asparagus africanus Lam., on some blood parameter and histopathology of liver and kidney in mice," BMC Research Notes, vol. 9, no. 1, article no. 1861, 2016.

[114] E. B. Izevbigie, J. L. Bryant, and A. Walker, "A novel natural inhibitor of extracellular signal-regulated kinases and human breast cancer cell growth, Experimental Biology and Medicine, vol. 229, no. 2, pp. 163-169, 2004.

[115] M. A. Eshete, E. Kelbessa, and G. Dalle, "Ethnobotanical study of medicinal plants in Guji Agro-pastoralists, Blue Hora District of Borana Zone," Journal of Medicinal Plants Studies, vol. 4, no. 2, pp. 170-184, 2016.
[116] WHO, WHO guidelines on good agricultural and collection practices (GACP) for medicinal plants, Geneva, Switzerland, 2003.

[117] WHO, Legal Status of Traditional Medicine and Complementary/Alternative Medicine: A Worldwide Review, World Health Organization, Switzerland, Geneva, 2001.

[118] M. Bishaw, "Promoting traditional medicine in Ethiopia: a brief historical review of government policy," Social Science \& Medicine, vol. 33, no. 2, pp. 193-200, 1991.

[119] A. Ashenafi, Current status of ABS implementation in Ethiopia, 2015.

[120] F. M. Birhanu, "Challenges and prospects of implementing the access and benefit sharing regime of the Convention on Biological Diversity in Africa: The case of Ethiopia," International Environmental Agreements: Politics, Law and Economics, vol. 10, no. 3, pp. 249-266, 2010.

[121] CBD: The Nagoya Protocol on Access and Benefit-sharing. https://wwwcbdint/abs/. Convention on Biological Diversity. CBD Secretariat. 


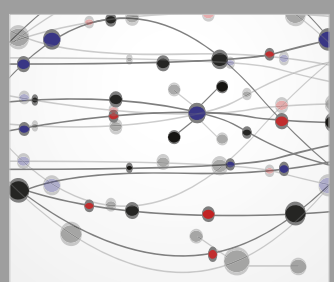

The Scientific World Journal
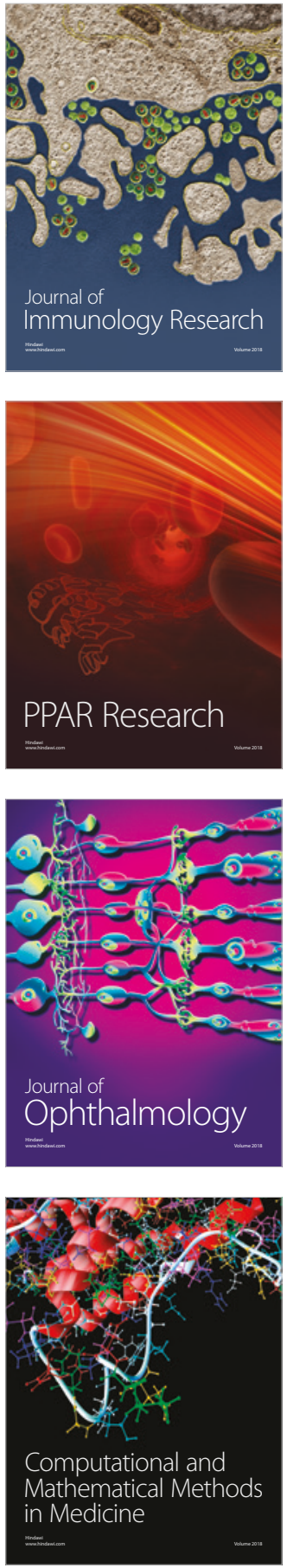

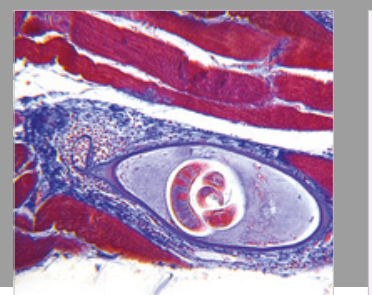

Gastroenterology Research and Practice

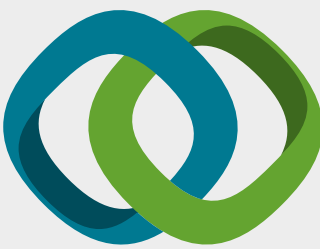

\section{Hindawi}

Submit your manuscripts at

www.hindawi.com
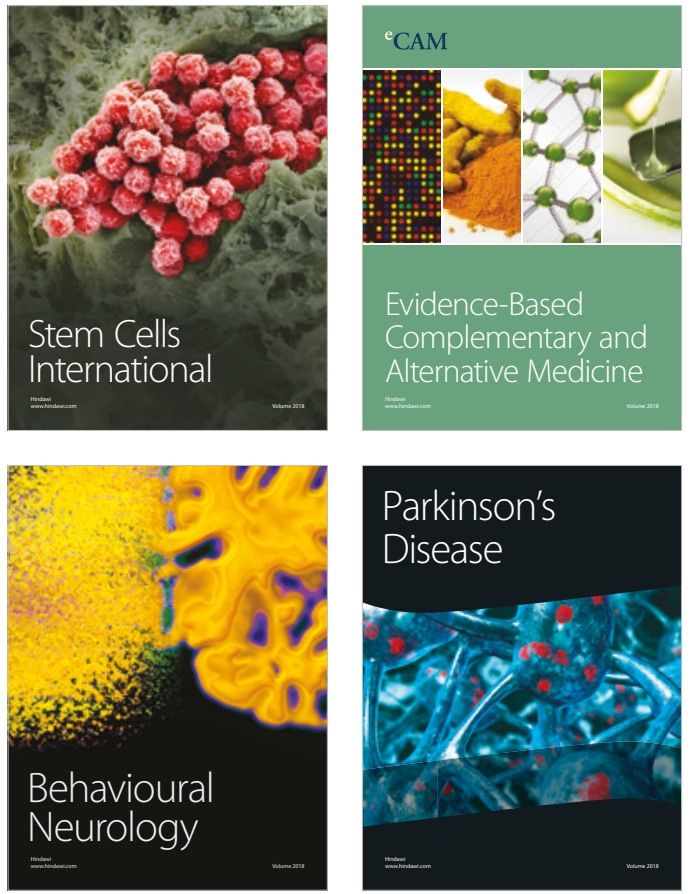

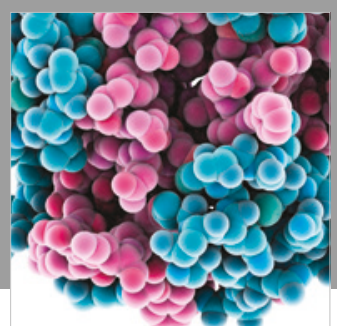

ournal of

Diabetes Research

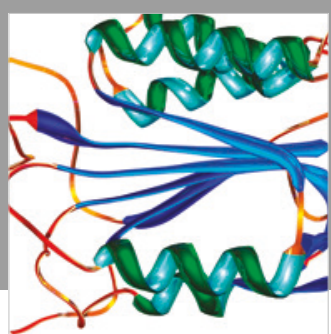

Disease Markers
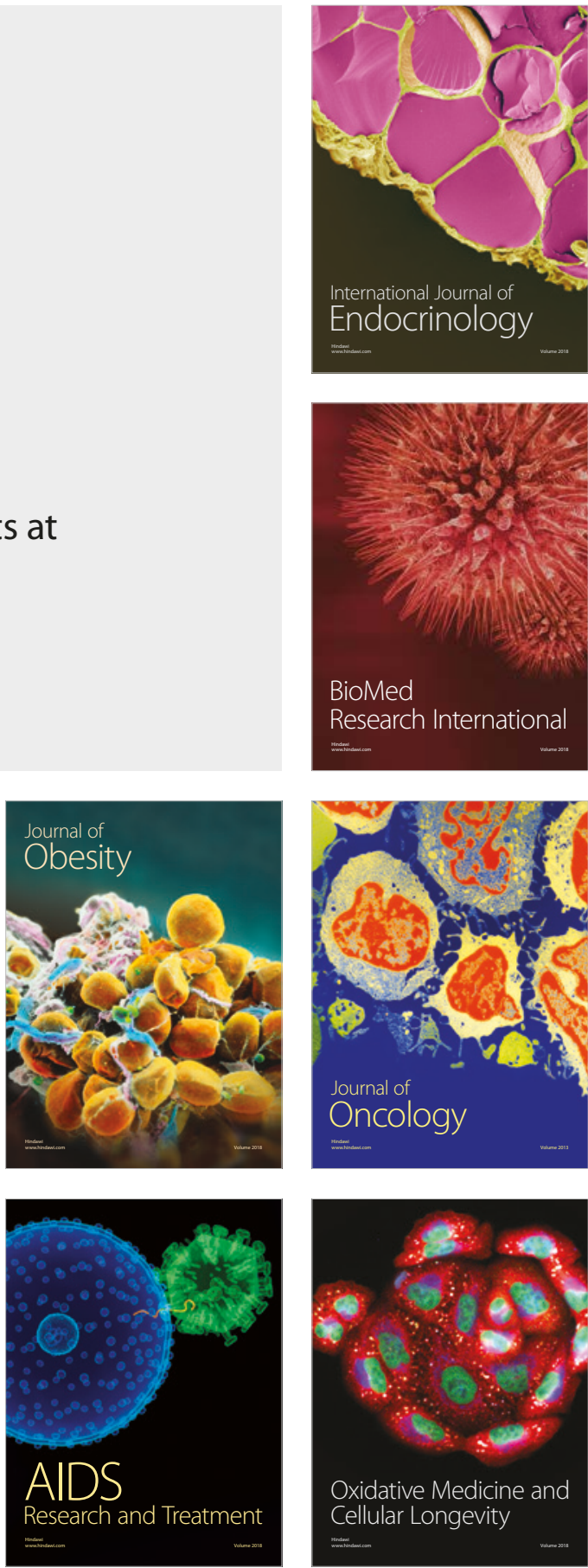